\title{
Improving simulated Amazon forest biomass and productivity by including spatial variation in biophysical parameters
}

\author{
A. D. A. Castanho ${ }^{1}$, M. T. Coe ${ }^{1}$, M. H. Costa ${ }^{2}$, Y. Malhi ${ }^{3}$, D. Galbraith ${ }^{4}$, and C. A. Quesada ${ }^{4,5}$ \\ ${ }^{1}$ The Woods Hole Research Center, 149 Woods Hole Rd., Falmouth, MA 02540, USA \\ ${ }^{2}$ Departamento de Engenharia Agrícola, Universidade Federal de Viçosa (UFV), Viçosa, MG, Brazil \\ ${ }^{3}$ Environmental Change Institute, School of Geography and the Environment, University of Oxford, Oxford, UK \\ ${ }^{4}$ School of Geography, University of Leeds, Leeds, UK \\ ${ }^{5}$ Instituto Nacional de Pesquisas da Amazônia, Manaus, Brazil
}

Correspondence to: A. D. A. Castanho (adacastanho@gmail.com)

Received: 31 July 2012 - Published in Biogeosciences Discuss.: 31 August 2012

Revised: 20 February 2013 - Accepted: 12 March 2013 - Published: 5 April 2013

\begin{abstract}
Dynamic vegetation models forced with spatially homogeneous biophysical parameters are capable of producing average productivity and biomass values for the Amazon basin forest biome that are close to the observed estimates, but these models are unable to reproduce observed spatial variability. Recent observational studies have shown substantial regional spatial variability of above-ground productivity and biomass across the Amazon basin, which is believed to be primarily driven by a combination of soil physical and chemical properties. In this study, spatial heterogeneity of vegetation properties is added to the Integrated Biosphere Simulator (IBIS) land surface model, and the simulated productivity and biomass of the Amazon basin are compared to observations from undisturbed forest. The maximum $\mathrm{RuBiCo}$ carboxylation capacity $\left(V_{\mathrm{cmax}}\right)$ and the woody biomass residence time $\left(\tau_{\mathrm{w}}\right)$ were found to be the most important properties determining the modeled spatial variation of above-ground woody net primary productivity and biomass, respectively. Spatial heterogeneity of these properties may lead to simulated spatial variability of 1.8 times in the woody net primary productivity $\left(\mathrm{NPP}_{\mathrm{w}}\right)$ and 2.8 times in the woody above-ground biomass $\left(\mathrm{AGB}_{\mathrm{W}}\right)$. The coefficient of correlation between the modeled and observed woody productivity improved from 0.10 with homogeneous parameters to 0.73 with spatially heterogeneous parameters, while the coefficient of correlation between the simulated and observed woody above-ground biomass improved from 0.33 to 0.88 . The results from our analyses with the IBIS dynamic vegetation model demonstrated that using single values for key
\end{abstract}

ecological parameters in the tropical forest biome severely limits simulation accuracy. Clearer understanding of the biophysical mechanisms that drive the spatial variability of carbon allocation, $\tau_{\mathrm{w}}$ and $V_{\mathrm{cmax}}$ is necessary to achieve further improvements to simulation accuracy.

\section{Introduction}

Tropical forests play an important role in the global carbon cycle, accounting for about one-third of the global net primary productivity and $55 \%$ of total global forest carbon (Pan et al., 2011; Malhi, 2010). The Amazon contains about $50 \%$ of the world's tropical forests (Pan et al., 2011). It is highly diverse in terms of climate, soil physical and chemical properties, and species composition (Davidson et al., 2012; Quesada et al., 2011; Fyllas et al., 2009; Phillips et al., 2004). However, most global vegetation models represent Amazon rainforests through a single set of parameters, which do not vary in space and thus fail to represent its complex spatial diversity. Dynamic Global Vegetation Models (DGVMs) are powerful tools for understanding past and potential future carbon fluxes and stocks. An accurate representation of spatial and temporal variability of the forest biophysical properties is essential for useful prediction of the future carbon cycle of Amazon forests. In this work we investigate the importance of representing spatial heterogeneity in vegetation properties in a commonly used DGVM. 
Field observations from undisturbed old-growth Amazon forest plots have recently quantified the regional variation of many forest attributes such as geological history (Higgins et al., 2011), soil properties (Quesada et al., 2011), foliar physiological properties (Fyllas et al., 2009; Lloyd et al., 2010), above-ground live biomass (Malhi et al., 2006; Baker et al., 2004b), above-ground wood productivity (Malhi et al., 2004), net primary productivity (Aragão et al., 2009; Malhi et al., 2009), and residence time of plant components (Phillips et al., 2004; Galbraith et al., 2013). These analyses have shown a general east-to-west gradient of tree structure and dynamics in Amazon forests. Forests in the west tend to have higher above-ground productivity and lower aboveground biomass, while those in the east and central Amazon are slower growing with higher above-ground biomass (Quesada et al., 2012; Malhi et al., 2004; Baker et al., 2004a). The east-west productivity and biomass gradient appears to be related to soil fertility and soil physical properties rather than to climate variations (Quesada et al., 2011). The soil properties appear to be related to geological history and the exposure of more fertile Miocene-age marine or lacustrine sediments in western Amazonia (Higgins et al., 2011).

Although the spatial variation in biomass and productivity has been measured and described and the relationship to edaphic properties noted, the underlying mechanisms are still not well understood (Malhi, 2012).

With respect to woody net primary productivity $\left(\mathrm{NPP}_{\mathrm{w}}\right)$ a number of mechanisms have been discussed in the literature. It has been suggested that the variability in wood productivity could be directly related to a shift in the balance of carbon allocation between roots and wood and/or respiration rate (Malhi et al., 2004). It is also possible that the $\mathrm{NPP}_{\mathrm{w}}$ spatial variability could be driven by variability in gross primary productivity (GPP) due to a potential limitation of photosynthesis by soil P availability (Quesada et al., 2012; Mercado et al., 2011; Lloyd et al., 2010). Data analyses by Malhi et al. (2004) also suggest that carbon use efficiency $(\mathrm{CUE}=\mathrm{NPP} / \mathrm{GPP})$ is higher in the west. This suggests that, in addition to a potentially higher GPP in the west there are also potentially higher autotrophic respiration rates in the less fertile soils of central Amazonia, making the CUE less efficient there. The direct effect of climate factors such as temperature, shortwave radiation and precipitation have been argued to be too small to explain the observed variability in the productivity (Malhi et al., 2004; Senna et al., 2009; Quesada et al., 2012; Galbraith et al., 2013).

The spatial variability of above-ground biomass across the Amazon basin has also been discussed in the literature. Field data have indicated the importance of wood density, canopy height and plant allometry in biomass estimates (Baker et al., 2004b; Malhi et al., 2006; Feldpausch et al., 2011). Woody biomass residence time has been suggested to be an important factor for better representation of above-ground biomass in vegetation models (Delbart et al., 2010). Field data show that the fast-growing forests in the western Amazon have lower wood density, lower residence time and therefore lower above-ground biomass than the slow-growing forests in the central and eastern Amazon (Phillips et al., 2004). The mechanisms that determine the spatial variability in plant residence time are still unresolved (Galbraith et al., 2013). It may be due to external factors such as soil physical properties, disturbance (e.g. landslides and erosion on steep slopes), or climate impacts on tree mortality rates, or intrinsic factors such as high growth rates intensifying light competition and associated tree mortality. Residence time is strongly correlated with soil physical properties, and forest growth rates are strongly related to available soil $\mathrm{P}$ and climate. However, the large-scale variation in biomass appears not to be explained by any of the edaphic properties alone (Quesada et al., 2012).

Dynamic global vegetation models predominately characterize the Amazon forest with tropical broadleaf evergreen trees as the plant functional type (PFT), which is represented by a set of parameters that are invariant in space and time. There is a growing awareness that such an approach is unable to capture spatial variations in key biophysical properties (Senna et al., 2009; Delbart et al., 2010; Fyllas et al., 2012). In this paper we address this issue through data integration and model improvement. We derive the most important parameters for simulating the spatial variability of above-ground woody net primary productivity and biomass. We use the Integrated Biosphere Simulator (IBIS) DGVM with spatially varying observational estimates of key biophysical parameters (woody biomass residence time $\left(\tau_{\mathrm{w}}\right)$, maximum ribulose-1,5-bisphosphate carboxylase/oxygenase (RuBisCO) carboxylation capacity $\left(V_{\mathrm{cmax}}\right)$, and NPP allocation to wood) to simulate $\mathrm{AGB}_{\mathrm{w}}$ and $\mathrm{NPP}_{\mathrm{w}}$ and evaluate model performance, in comparison to field data. We create basin-wide raster data sets of the key parameters by extrapolation of the site-specific heterogeneous parameters. Finally, we evaluate the impact of using spatially varying parameters on simulated $\mathrm{AGB}_{\mathrm{w}}$ and $\mathrm{NPP}_{\mathrm{w}}$ throughout the Amazon.

\section{Material and methods}

The study area is the Amazon region (Fig. 1). The spatial analyses applied are at $1^{\circ} \times 1^{\circ}$ horizontal resolution. The $1^{\circ} \times 1^{\circ}$ spatial resolution has been chosen as a compromise between the spatial resolution of the model drivers (e.g. climate and soil properties) and computer run-time. In this section we describe (1) the IBIS dynamic vegetation model used, (2) the field data used in calibration and validation, and (3) the sequence of model simulation exercises.

\subsection{IBIS 2.6. Integrated Biosphere Simulator}

IBIS is a comprehensive model of terrestrial biospheric processes (Foley et al., 1996; Kucharik et al., 2000). The model uses an integrated framework based on land surface biophysics (canopy and soil physics, plant physiology), 


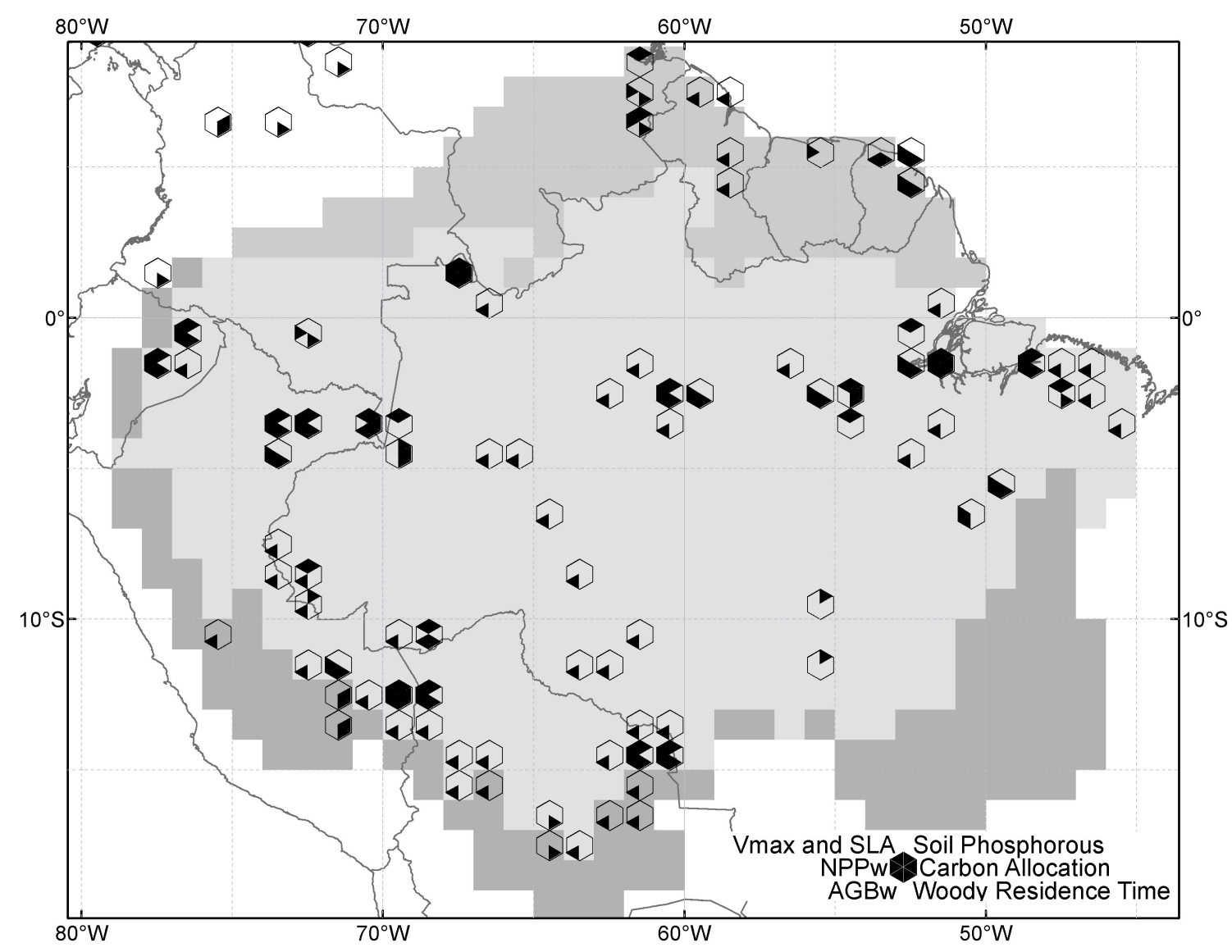

Fig. 1. Locations of the main field observation data: woody above-ground biomass (Malhi et al., 2006); woody net primary productivity (Malhi et al., 2004); maximum carboxylation capacity of RuBisCO and specific leaf area index (Fyllas et al., 2009); total soil Pposphorus (Quesada et al., 2010); woody carbon allocation (Malhi et al., 2011); woody residence time (Galbraith et al., 2013). Shaded areas include the Amazonian sensu stricto (Amazon basin below $700 \mathrm{~m}$ a.s.l., light gray) with an estimated area of $\sim 5.65 \mathrm{million}^{\mathrm{km}}{ }^{2}$, Amazon River basin (light gray including southeast Planalto, western Andes in dark gray) and tropical forest areas in the north (Guiana, dark gray) (Eva et al., 2005). Each field site that provided data is marked by a hexagon, which is divided into 6 wedges. Each wedge corresponds to a particular variable (see key in lower right). If a particular field variable is available at a site, the wedge corresponding to it is black. For example if woody above-ground biomass $\left(\mathrm{AGB}_{\mathrm{W}}\right)$ was collected at a particular site, the lower left wedge is black.

vegetation phenology, vegetation dynamics and competition, terrestrial carbon and nutrient cycling. IBIS has been previously validated and applied to the Amazon (Senna et al., 2009; Delire and Foley, 1999; Foley et al., 2002; Coe et al., 2007). In those studies the model adequately simulated the carbon, energy and water budgets of the basin. However, the authors in those studies pointed out the need for better spatial representation of parameters to improve model performance in comparison with observations across the Amazon. Detailed descriptions of the model can be found in those publications.

The IBIS land surface module is derived from the land surface transfer model (LSX) (Thompson and Pollard 1995a, b). Land surface processes are represented by two vegetation layers (woody and herbaceous plants), and six soil layers (to simulate the diurnal and seasonal variations of heat and moisture in the total soil depth). The dynamics of soil volumetric water content are simulated for each layer. The soil water infiltration rate is based on the Green-Ampt formulation (Green and Ampt, 1911; Li et al., 2005, 2006). The model has 12 PFTs that compete for light and water, using different ecological strategies. Nutrient competition is not currently included. The model allows for one or more PFT per grid cell that combined define a vegetation type. In IBIS the Amazon basin is predominantly represented by the tropical broadleaf evergreen tree PFT. The goal of this study is to clarify the importance for carbon cycle simulation of using more detailed spatially-varying parameters within this single plant functional type.

\subsubsection{Model review}

In this section we perform a brief review of the main processes that involve NPP allocation, $\tau_{\mathrm{w}}$ and $V_{\mathrm{cmax}}$ in 
simulated woody above-ground productivity and aboveground biomass in the IBIS numerical model.

NPP allocation refers to the partitioning of new growth into different plant tissues including wood, leaf and fine root. Allocation is very important for simulating the carbon cycle as it directly influences long-term carbon storage (Malhi et al., 2011). Furthermore, the amount of carbon allocated to leaves influences the total canopy photosynthesis, and the amount of carbon allocated to roots influences the amount of water uptake and nutrient acquisition, among other processes. Carbon partitioning varies between numerical models. Some models use a dynamic carbon allocation, while others are based on a predefined ratio between main plant compartments fixed by each PFT (Malhi et al., 2011). The original configuration of IBIS used a fixed partitioning of net $\mathrm{C}$ of $50 \%$ to wood $\left(\alpha_{\mathrm{w}}\right), 30 \%$ to leaves $\left(\alpha_{1}\right)$ and $20 \%$ to roots $\left(\alpha_{\mathrm{r}}\right)$ for the tropical broadleaf evergreen trees PFT (Eq. 1).

$\mathrm{NPP}_{i}=\alpha_{i} \mathrm{NPP}$

The biomass residence time $(\tau)$ defines the lifetime of a unit of biomass in the plant. Many global vegetation models assume a predefined and constant value of $\tau$ for each PFT and for each plant compartment $\left(\operatorname{wood}\left(\tau_{\mathrm{w}}\right)\right.$, leaf $\left(\tau_{1}\right)$ and fine root $\left.\left(\tau_{\mathrm{r}}\right)\right)$. For tropical broadleaf evergreen trees in IBIS, $\tau_{\mathrm{w}}$ is set to $25 \mathrm{yr}$, while $\left(\tau_{1}\right)$ and $\left(\tau_{\mathrm{r}}\right)$ are set to $1 \mathrm{yr}$. Other global vegetation models assume a constant $\tau_{\mathrm{w}}$ for tropical forests, ranging from 20 to $200 \mathrm{yr}$. The woody biomass residence time is a key parameter for accurately simulating biomass stocks in an ecosystem. The change in the biomass $(M)$ of an individual plant compartment ( $i$ : wood, leaf or fine root) over a period of time is described in Eq. (2):

$$
\frac{\mathrm{d} M_{i}}{\mathrm{~d} t}=\alpha_{i} \mathrm{NPP}-\frac{M_{i}}{\tau_{i}} .
$$

$\alpha$ represents the fraction of net primary productivity (NPP) allocated to biomass pool $i$, and $\tau$ is the residence time of that pool, expressed in years (Foley et al., 1996).

$V_{\text {cmax }}$ refers to the photosynthetic capacity of the plant. It is the carboxylation capacity of the enzyme RuBisCO, which catalyzes the $\mathrm{CO}_{2}$ reaction during its assimilation process in leaves ( $\mathrm{RuBisCO}$ is the $\mathrm{CO}_{2}$ receptor molecule in the Calvin cycle). It is directly related to the GPP of the plant, and in IBIS it is defined initially for tropical broadleaf evergreen trees as $65\left(\mu \mathrm{mol} \mathrm{CO} \mathrm{m}^{-2} \mathrm{~s}^{-1}\right)$.

\subsection{Field observation database and basin-wide extrapolations}

We have assembled a wide range of published data from field observations at several sites across the Amazon basin (Fig. 1). The sites are all in undisturbed old-growth forest, with most of them being part of the RAINFOR network ("Rede Amazónica de Inventarios Forestales", Amazon Forest Inventory Network; http://www.rainfor.org/). The RAINFOR project is an international effort to monitor structure, composition and dynamics of the Amazonian forest in order to better understand their relationship to soil and climate (Malhi et al., 2002; Peacock et al., 2007). The RAINFOR field data are in generally based on one-hectare plots (see references for more detailed information). In this study, plot data are aggregated to the 1-degree horizontal resolution used by IBIS.

\subsubsection{Carbon allocation}

There are few plot measurements of carbon allocation to stems, roots, and leaves reported in the literature. Malhi et al. (2011) compiled a carbon allocation database for tropical forests worldwide. They report the partition of carbon between wood, fine roots and leaves for 10 plots in the Amazonian basin that represent 6 sites at the $1^{\circ} \times 1^{\circ}$ grid cell resolution of the model (Table 1). The authors showed that in general there is nearly equal allocation of new carbon between wood, leaves and fine roots. Aragão et al. (2009) suggested that the $\mathrm{C}$ allocation partition appears related to soil texture rather than soil fertility. The authors identified that carbon allocation to roots decreases with increasing soil clay content. They argue that this happens because, in well-drained sandy soils, roots grow with less resistance from the soil and have faster water absorption. Following the hypothesis of Aragão et al. (2009) we tested the correlation between percent sand content with both fine-root and leaf carbon. We obtained a similar correlation to their study (Fig. 2, Eq. 3 in Table 1). The carbon allocation between wood, leaves and fine roots for the whole basin is estimated based on the regressions (Eq. 3, Table 1) applied to the soil texture map (Quesada et al., 2010). The correlations between carbon allocation and soil texture are available for a small number of sites, and may be limited by other factors that are either not well known or are not well represented by this limited database. Applying Eq. 3 to the entire basin, the estimated woody carbon allocation for the region varies between 30 and $40 \%$ (Fig. 5a, background map). This estimate does not reproduce the amplitude of the site-specific measurement of carbon allocation (25-50\%) (Fig. 5a, bullets), which suggests that the assumption of this hypothesis does not critically affect the final results (Supplement Table B).

\subsubsection{Woody residence time $\left(\tau_{\omega}\right)$}

Woody biomass residence time $\left(\tau_{\omega}\right)$ has been estimated from field measurements, and a strong spatial variability has been reported (25-100 yr) (Phillips et al., 2004). Spatially varying $\tau_{\omega}$ is included as an input parameterization in the model. In this work we use the compiled data on $\tau_{\omega}$ from Galbraith et al. (2013), which is in terms of carbon residence time, more appropriate for this study. The data set includes analyses of 129 plots across Amazonia for 5-25 yr time series between 1971 and 2011 (Table 1) (Galbraith et al., 2013). There are 34 $1^{\circ} \times 1^{\circ}$ grid cells associated with these sites (Fig. 1). There 


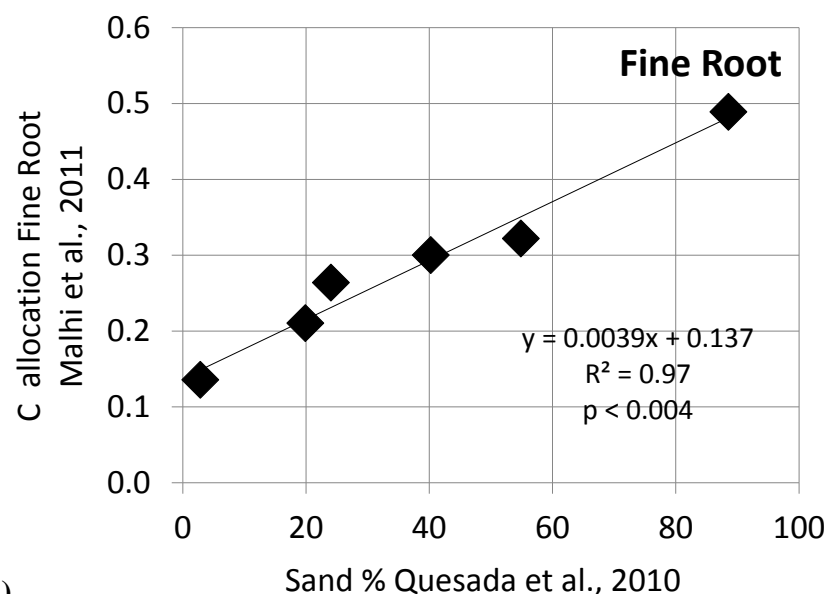

(a)

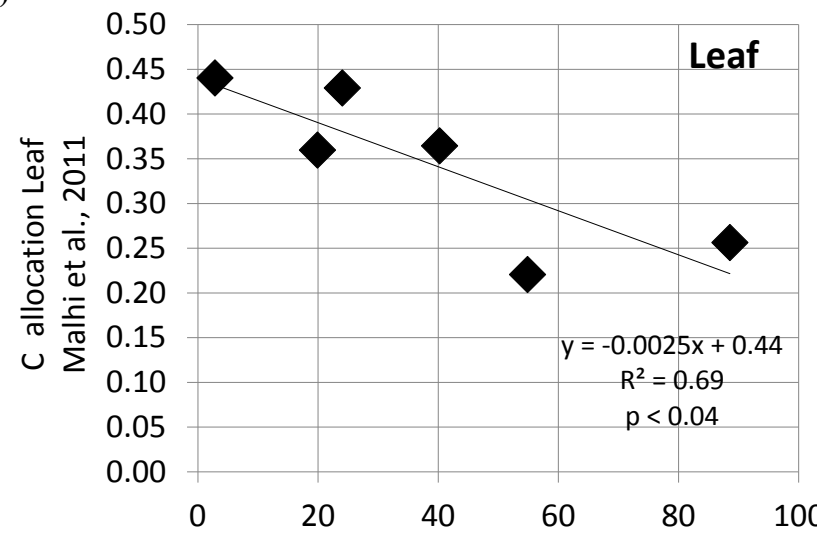

(b)

Sand \% Quesada et al., 2010

Fig. 2. The relationship between fraction of NPP allocation to fine roots and percentage of sand in soil (a), same for carbon allocation to leaves and percentage of sand in soil (b) (Malhi et al., 2011; Quesada et al., 2010).

are strong indications that $\tau_{\omega}$ is correlated to soil physical properties (Quesada et al., 2012); however the mechanisms that would explain the spatial variability of $\tau_{\omega}$ are not completely understood (Quesada et al., 2012, Galbraith et al., 2013). For this reason we scale up $\tau_{\mathrm{w}}$ to the entire basin, using simple kriging interpolation of the field data points (Fig. 5b).

\subsubsection{Total soil phosphorus (Ptot)}

Phosphorus (P) is known to be a limiting factor for productivity of mature tropical forests (Vitousek, 1984; Lloyd et al., 2010; Mercado et al., 2011); therefore it is used in this study to represent the soil fertility limitation in our model. The total available $\mathrm{P}$ in this work is used to estimate the maximum carboxylation capacity of RuBisCO. Quesada et al. (2010) performed extensive collection and analyses of soil data at 71 sites with varying soil properties throughout Amazonia. The 71 sites are grouped into $261^{\circ} \times 1^{\circ}$ grid cells (Table 1 , Fig. 1). Based on field data (Quesada et al., 2010; 2011) we defined a relationship between total soil $\mathrm{P}$ measured (average to depth from 0 to $0.3 \mathrm{~m}$ ) at the site level and the respective soil class (Fig. 3). The relationship between total $\mathrm{P}$ and the labile $\mathrm{P}$ pools is not linear and could depend on external factors such as soil texture for example. The $\mathrm{P}$ map estimate we present here is focused on the large-scale variability of $\mathrm{P}$ in soil where total $\mathrm{P}$ varies from $50-500 \mathrm{mg} \mathrm{Kg}^{-1}$. The total soil P correlates significantly $\left(r^{2}=0.65, p<0.005\right)$ with $\mathrm{P}$ in leaves.

Quesada et al. (2011) presented a map of basin-wide distribution of soil coverage for each reference soil group. Based on the relationship presented in Fig. 3 and the soil class map, we created a spatial map of total soil $\mathrm{P}$ content (the average by depth from 0 to $0.3 \mathrm{~m}$ ) of each $1^{\circ} \times 1^{\circ}$ grid cell in the Amazon (Fig. 4). Due to the large variability of soil types within the grid cell, we expect to see discrepancies between the site level measurement and the P content derived for the grid cell. The derived total soil $\mathrm{P}$ map qualitatively reproduces the east $\left(100 \mathrm{mg} \mathrm{kg}^{-1}\right)$ to west $\left(450 \mathrm{mg} \mathrm{kg}^{-1}\right)$ increase in fertility as observed in the independent site level measurements. Lowest total soil P occurs in northern Brazil and southern Venezuela, which coincides with the highest values of soil sand content (Fig. 4). Total derived $\mathrm{P}$ values are estimated to exceed $300 \mathrm{mg} \mathrm{kg}^{-1}$ in a portion of central Amazonia, but there are no observations to corroborate these estimates. Lacking further field measurements to validate our map, we use it cautiously in this study as a means of understanding the sensitivity of simulated biomass to fertility variation.

\subsubsection{Maximum carboxylation capacity of RuBisCO $\left(V_{\text {cmax }}\right)$}

Maximum carboxylation capacity of RuBisCO ( $\left.V_{\mathrm{cmax}}\right)$ and specific leaf area index (SLA) are important properties for simulating photosynthesis. We collected the existing data on these to explore their spatial distribution in the Amazon Basin and to use as input parameterizations in the model. Fyllas et al. (2009) analyzed leaf properties at 62 RAINFOR plots across the Amazon Basin. These data, when averaged to our grid cell of $1^{\circ} \times 1^{\circ}$, represent 22 data points (Fig. 1, Table 1). The authors present data for leaf mass per unit area (the inverse of SLA), and leaf concentration of the main growth-limiting nutrients such as $\mathrm{N}$ and $\mathrm{P}$. Their analyses showed that soil fertility is one of the most important predictors for observed higher nutrient concentration in leaves. Mercado et al. (2009) noted a correlation between $V_{\mathrm{cmax}} \mathrm{ob}-$ served from the field and the concentrations of $\mathrm{P}$ in leaves. We developed a similar regression equation to that of Mercado et al. $(2009,2011)$ but between $V_{\text {cmax }}$ and total P concentration in soil instead of the $\mathrm{P}$ concentration in leaves (Fig. 3b, Eq. 4 in Table 1).

The advantage of this empirical regression with respect to soil $\mathrm{P}$ is the ability to estimate $V_{\mathrm{cmax}}$ for the whole basin based on Eq. (4) (Table 1) and the map of total soil P concentration (Fig. 4). The $V_{\text {cmax }}$ spatial distribution shows the same spatial structure as the $\mathrm{P}$ map, with a gradient from 


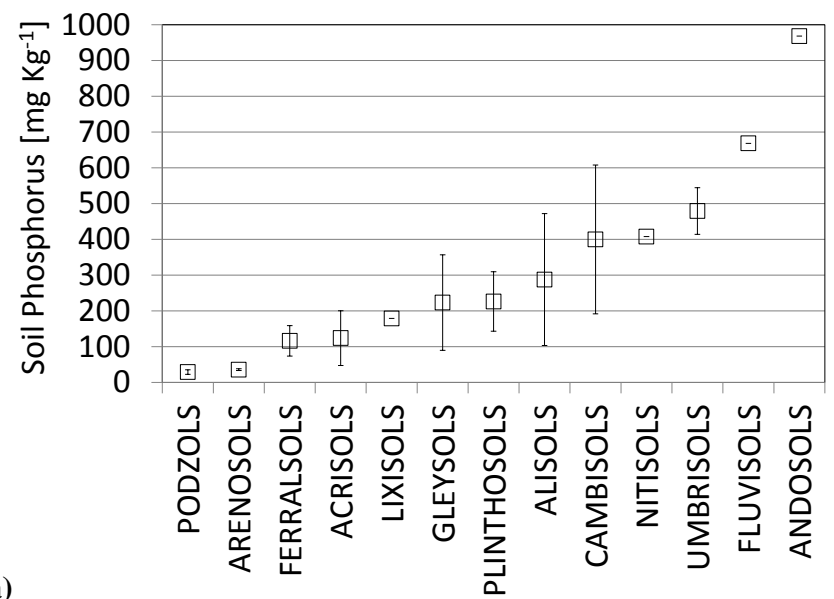

(a)

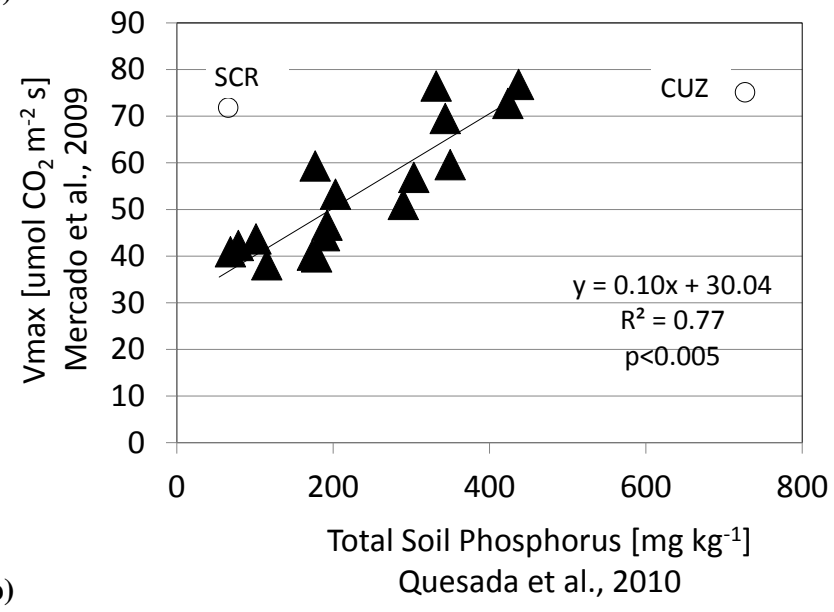

Fig. 3. (a) Total soil phosphorus aggregated by soil type, based on field data from Amazonia, showing the average and standard deviation for each soil class; (b) regression between $V_{\text {cmax }}$ (Mercado et al., 2009) and total soil P (average depth from 0 to $0.3 \mathrm{~m}$; Quesada et al., 2010), excluding CUZ and SCR field site (Supplement D).

west to east (Fig. 5c). There is in general a good agreement between field estimates of $V_{\text {cmax }}$ (Mercado et al., 2009) and the estimated map in this work (Fig. 5c). The San Carlos do Rio Negro (SCR, Venezuela) site represents a significant outlier, as the observed $V_{\text {cmax }}$ at this site (ranging around $65 \mu \mathrm{mol} \mathrm{m}{ }^{-2} \mathrm{~s}^{-1}$; Mercado et al., 2011) is considerably higher than the estimated value based on soil $\mathrm{P}$ content (ranging around $35 \mu \mathrm{mol} \mathrm{m} \mathrm{m}^{-2} \mathrm{~s}^{-1}$, Fig. 5c). The reason for this difference is not clear but may be due to the large differences between foliar P (Fyllas et al., 2009) and soil P for this specific site (Quesada et al., 2010). The limitation of the linear regression between $V_{\text {cmax }}$ and total soil $\mathrm{P}$ is that it does not reproduce the saturation in $V_{\text {cmax }}$ due to high levels of $\mathrm{P}$ content. One example of this is the high $V_{\text {cmax }}$ value estimated in Cuzco Amazonico (CUZ, Peru) (Fig. 5c) due to the elevated total soil P in this site (Fig. 4). Mercado et al. (2011) suggested the use of a modified photosynthesis model that includes both $\mathrm{P}$ and $\mathrm{N}$ limitation of the main photosynthetic

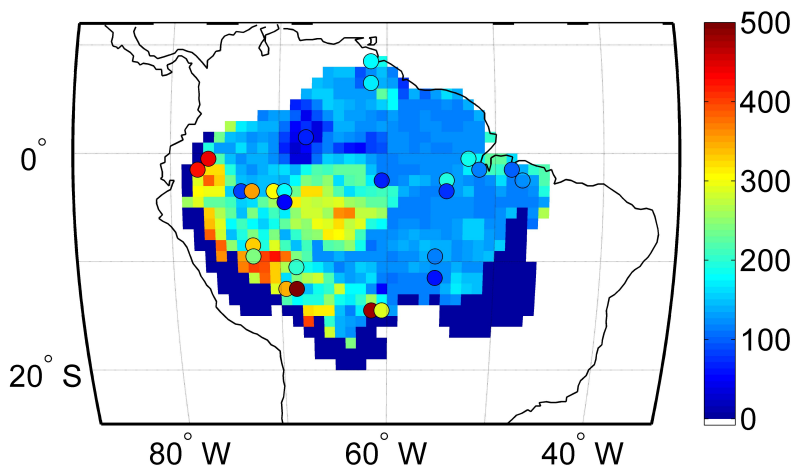

Fig. 4. Estimated total soil phosphorus map in $\mathrm{mg} \mathrm{kg}^{-1}$ (average depth from 0 to $0.3 \mathrm{~m}$ ). The dots represent averaged field plot measurements in one-degree grid cells (Quesada et al., 2010). The total soil phosphorus map (background) is derived based on soil class map and the relationship between site level total soil P content and soil class (Fig. 3).

parameters, as described in Domingues et al. (2005, 2010). More detailed physiological analyses are important for a better definition of the relation between $V_{\mathrm{cmax}}$ and the $\mathrm{P}$ limitation. There are no clear relationships between SLA and other biophysical properties; therefore we interpolated the site values to the entire basin using the kriging interpolation method (Fig. 5d).

\subsubsection{Above-ground woody net primary productivity $\left(\mathbf{N P P}_{\mathbf{w}}\right)$}

The above-ground wood net primary productivity $\left(\mathrm{NPP}_{\mathrm{w}}\right)$ field database is used in this work for comparison to the simulated $\mathrm{NPP}_{\mathrm{w}}$. IBIS, like many other ecosystem models, simulates a generic woody biomass pool that includes all aboveground wood and coarse roots. Therefore, to facilitate comparison with the field data, which is above-ground woody productivity only, the simulated woody net primary productivity was divided by 1.21 to remove the below-ground coarse-root fraction of the simulated NPP wood as suggested in Houghton et al. (2001). Malhi et al. (2004) present a large data set of above-ground coarse wood productivity in 104 neotropical forest plots. Their sites are all located at an elevation lower than $1000 \mathrm{~m}$, in mixed-age old-growth humid forest, and with no human disturbance. For comparison with our simulated results these data are aggregated to the $1^{\circ} \times 1^{\circ}$ grid cell resolution of this study, representing 25 grid-points across Amazonia (Fig. 1, Table 1). There is high productivity in west and low productivity in central and eastern Amazonia, varying in space from 0.15 up to $0.55 \mathrm{~kg}-\mathrm{C} \mathrm{m}^{2} \mathrm{yr}^{-1}$, with an overall variability of $260 \%$ (or $0.55 / 0.15=3.6$ times) (Fig. 6a). 
Table 1. List of field data used in this study with the respective reference in the literature. The original number of plots from each study is presented in column A, the respective number of grid cells at $1^{\circ} \times 1^{\circ}$ resolution is presented in column $\mathrm{B}$. The methods for upscaling and the regression equations used are presented. The table is divided into field data used for input parameterization in the model and field data of woody net primary productivity and woody above-ground biomass used for model output validation.

\begin{tabular}{|c|c|c|c|c|c|}
\hline $\begin{array}{l}\text { Property } \\
\text { [unit] }\end{array}$ & Paper & \# plots & $\begin{array}{l}\text { \# grid cells in } \\
\text { studied region }\end{array}$ & $\begin{array}{l}\text { Method of } \\
\text { upscaling }\end{array}$ & $\begin{array}{l}\text { Regression } \\
\text { equations }\end{array}$ \\
\hline
\end{tabular}

\begin{tabular}{|c|c|c|c|c|c|}
\hline \multicolumn{6}{|l|}{ Model parameterization } \\
\hline $\begin{array}{l}\text { Carbon allocation } \\
\text { to wood, leaves and } \\
\text { roots [fraction] }\end{array}$ & $\begin{array}{l}\text { Malhi et al. (2011), } \\
\text { Aragão et al. (2009) }\end{array}$ & 10 & 6 & $\begin{array}{l}\text { Use Eq. (3) to retrieve } \\
\text { carbon allocation as a } \\
\text { function of sand } \\
\text { fraction given by } \\
\text { Quesada et al. (2010) } \\
\text { soil texture map }\end{array}$ & $\begin{array}{l}\text { Equation }(3) \\
C_{\text {root }}=0.0039 \cdot \text { Sand }[\%]+0.137 \\
R^{2}=0.97 ; p<0.004 \\
C_{\text {leaf }}=-0.0025 \cdot \text { Sand }[\%]+0.44 \\
R^{2}=0.69 ; p<0.04 \\
C_{\text {wood }}=1-C_{\text {root }}-C_{\text {leaf }}\end{array}$ \\
\hline $\begin{array}{l}\text { Woody biomass } \\
\text { residence time [yr] }\end{array}$ & Galbraith et al. (2013) & 129 & 34 & Kriging interpolation & - \\
\hline $\begin{array}{l}\text { Soil total phos- } \\
\text { phorus content }(\mathrm{P}) \\
{\left[\mathrm{mg} \mathrm{kg}^{-1}\right]}\end{array}$ & Quesada et al. (2010) & 71 & 26 & $\begin{array}{l}\text { Use relation obtained } \\
\text { (Fig. 3a) to retrieve } \\
\text { soil total P as a func- } \\
\text { tion of soil class } \\
\text { given by Quesada et } \\
\text { al. (2011) soil class } \\
\text { map }\end{array}$ & $\begin{array}{l}\text { (Soil total P site level }) \times(\text { soil } \\
\text { class site Level }) \\
\text { Fig. 3a }\end{array}$ \\
\hline $\begin{array}{l}\text { Maximum carboxy- } \\
\text { lation capacity of } \\
\operatorname{RuBisCO}\left(V_{\mathrm{cmax}}\right) \\
{\left[\mu \mathrm{mol} \mathrm{CO} 2 \mathrm{~m}^{-2} \mathrm{~s}^{-1}\right]}\end{array}$ & $\begin{array}{l}\text { Fyllas et al. (2009) } \\
\text { (Phosphorus leaf site) }\end{array}$ & 62 & 22 & $\begin{array}{l}\text { Use Eq. (4) to retrieve } \\
V_{\mathrm{cmax}} \text { as a function of } \\
\text { soil total phosphorus } \\
\text { map (defined above) }\end{array}$ & $\begin{array}{l}\text { Equation }(4) \\
V_{\mathrm{cmax}}=0.1013 \cdot \mathrm{P} \\
{\left[\mathrm{mg} \mathrm{kg}^{-1}\right]+30.037} \\
R^{2}=0.77 p<0.005\end{array}$ \\
\hline $\begin{array}{l}\text { Specific leaf area } \\
\text { index (SLA) } \\
{\left[\mathrm{m}^{2} \mathrm{~kg}^{-1}\right]}\end{array}$ & Fyllas et al. (2009) & 62 & 22 & Kriging interpolation & - \\
\hline \multicolumn{6}{|c|}{ Model output validation data } \\
\hline $\begin{array}{l}\text { Woody net primary } \\
\text { productivity }\left(\mathrm{NPP}_{\mathrm{W}}\right) \\
{\left[\mathrm{kg}-\mathrm{C} \mathrm{m}^{-2} \mathrm{yr}^{-1}\right]}\end{array}$ & Malhi et al. (2004) & 104 & 25 & - & - \\
\hline $\begin{array}{l}\text { Woody above-ground } \\
\text { biomass }\left(\mathrm{AGB}_{\mathrm{W}}\right) \\
{\left[\mathrm{kg}-\mathrm{C} \mathrm{m} \mathrm{m}^{-2}\right]}\end{array}$ & Malhi et al. (2006) & 227 & 69 & - & - \\
\hline
\end{tabular}

\subsubsection{Above-ground woody biomass $\left(\mathrm{AGB}_{\mathrm{w}}\right)$}

Malhi et al. (2006) present a synthesis of data on woody above-ground live biomass of old-growth lowland tropical forest for 227 plots across South America. This data was rescaled to the one-degree grid resolution, resulting in 69 sites for comparison with our simulation results (Fig. 1, Table 1). The spatial distribution of biomass shows high biomass in the slow-growing central Amazonia forest and Guyana, with low biomass in the western faster-growing forests and the dryer southern and eastern margins. The observed woody biomass ranges from 9 up to $20 \mathrm{~kg}-\mathrm{C} \mathrm{m}^{-2}$, with a spatial variability of $120 \%$ (or $20 / 9=2.2$ times) among forest sites (Fig. 6b).

\subsection{Model configuration}

In order to quantify the response of IBIS to spatially varying parameters, we performed a suite of simulations in 4 different categories (Table 2). The first category is a simulation over the entire Amazon basin that uses the original configuration of the IBIS model. This simulation serves as a reference to the other experiments and is referred to as the control simulation (CA). The second simulation assumes the original configuration CA but alters the allocation of NPP to wood, 

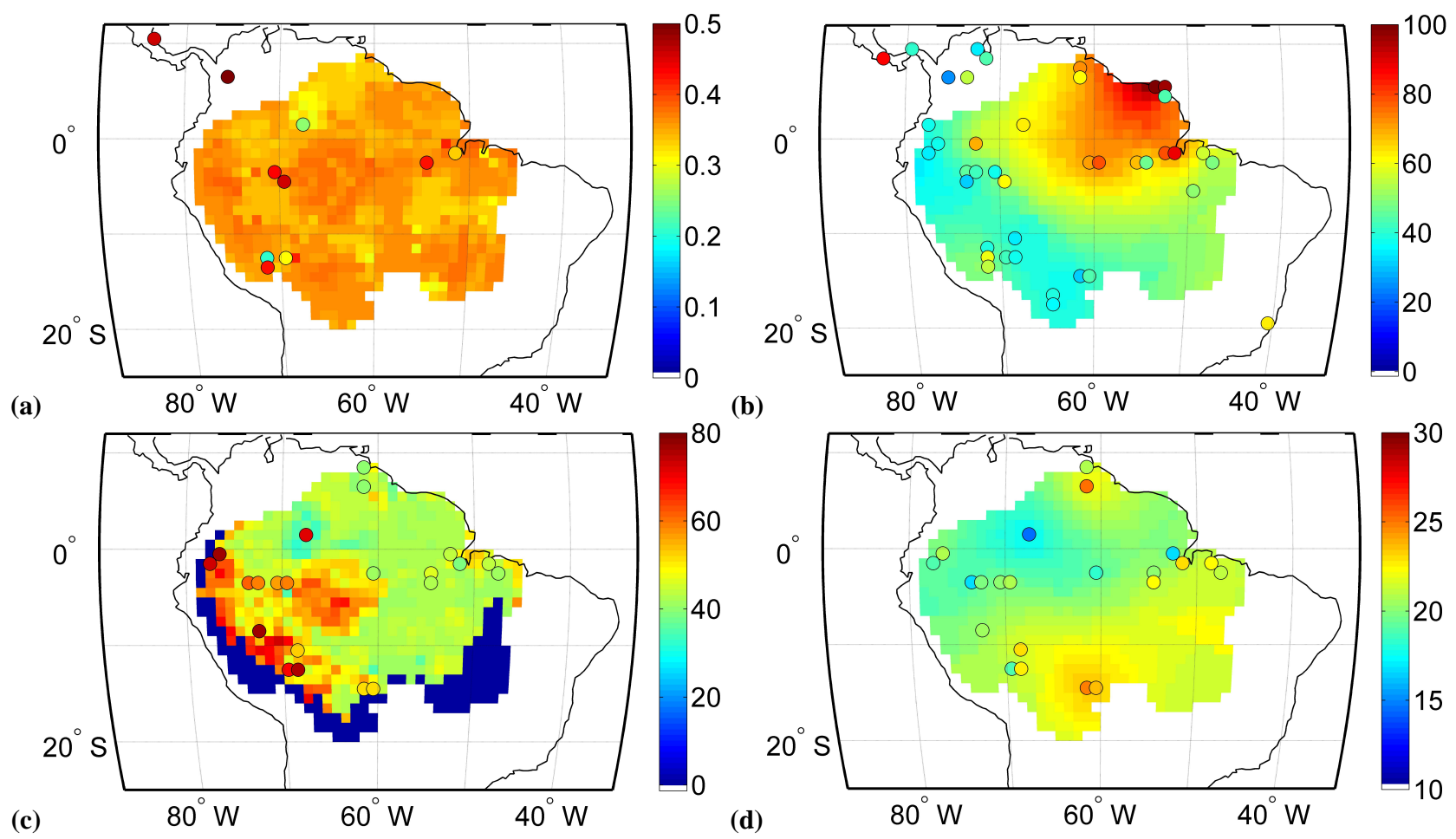

(b)

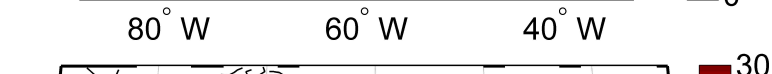

80

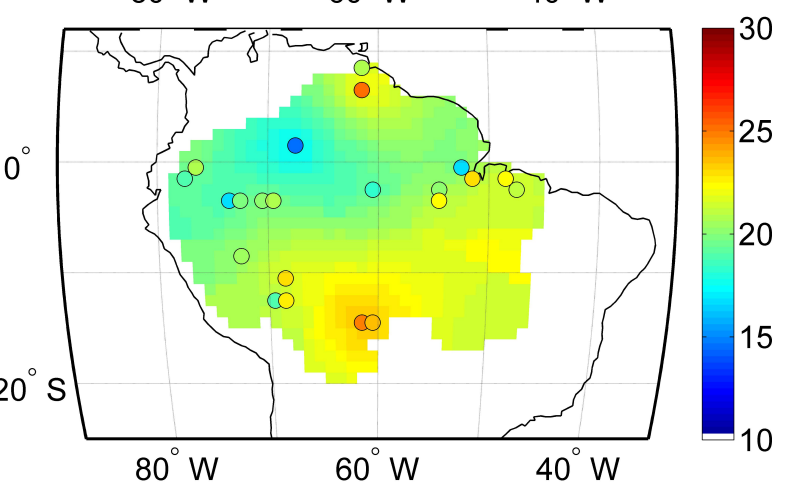

Fig. 5. Site-specific field data (dots) and the extrapolated map (background): (a) carbon allocation to wood [fraction], where the extrapolated map is based on sand fraction map; (b) woody biomass residence time [years], where the extrapolation is by kriging interpolation of site data; (c) maximum carboxylation capacity of RuBisCO $\left[\mu \mathrm{mol} \mathrm{CO} \mathrm{Cm}^{-2} \mathrm{~s}^{-1}\right.$ ], where the extrapolation method is based on total soil P map; (d) specific leaf area index $\left[\mathrm{m}^{2} \mathrm{~kg}^{-1}\right]$, where the extrapolation is by kriging interpolation of site data.

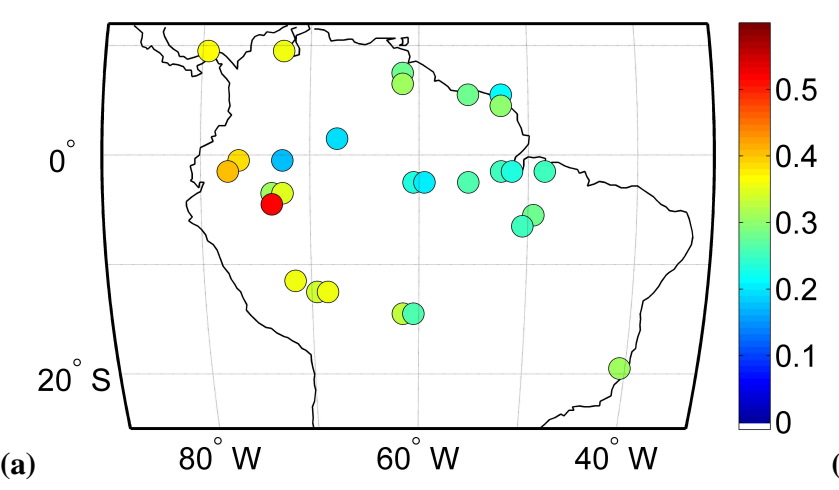

(b)

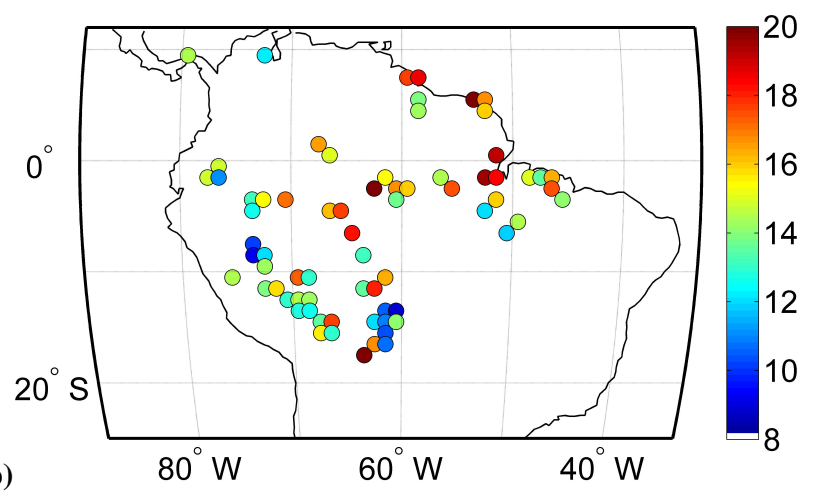

Fig. 6. (a) Estimated wood net primary productivity $\left(\mathrm{NPP}_{\mathrm{w}}\left[\mathrm{kg}-\mathrm{C} \mathrm{m}^{-2} \mathrm{yr}^{-1}\right]\right)$ and (b) wood live above-ground biomass $\left(\mathrm{AGB} \mathrm{w}_{\mathrm{w}}\left[\mathrm{kg}-\mathrm{C} \mathrm{m}^{-2}\right]\right)$, based on field data by Malhi et al. (2004) and (2006), respectively. Dots represent the average from measurement plots averaged to $1^{\circ} \times 1^{\circ}$ grid cell.

foliage and roots so that it is more consistent with observations, allocating one-third for each component $(34 \%, 33 \%$ and $33 \%$, respectively) (SA3a) (Malhi et al., 2011). In these tests, constant parameter values are assigned and fixed in space for the entire Amazon basin (homogeneous parameterization). The third simulation category referred to as the site level simulation (SS) tests the importance of using the spatially heterogeneous field data to represent the fundamental parameters. In these simulations the model is run only at the site level with the parameters from our database (Fig. 5, dots and Table 1). Comparison of these simulations (SS) with CA and SA3a and with observations provides an understanding of the ability of the model to simulate the productivity and biomass at individual locations. The fourth simulation category uses the basin-wide spatially varying parameter values (Fig. 5, background map and Table 1) derived in this study. The results of this exercise (referred to as RS), when compared to CA, SA3a and the observations, quantify the value 
of using best estimates of basin-wide parameters to derive productivity and biomass values across the Amazon. We considered spatial variation in carbon allocation to wood, leaves and fine roots, woody biomass residence time, maximum carboxylation capacity of RuBisCO ( $\left.V_{\mathrm{cmax}}\right)$ and SLA (Table 2$)$. The specific parameter values and simulation runs are summarized in Table 2.

The model was forced with prescribed climate based on the Sheffield et al. (2006) database, which is a combination of global observation-based data sets and reanalysis data from the National Center for Environmental Prediction - National Center for Atmospheric Research (NCEP-NCAR). The data set is available from 1970 to 2008 ( $39 \mathrm{yr}$ ), has one-degree spatial resolution and $3 \mathrm{~h}$ time resolution, which was linearly interpolated to one hour.

The model simulations were run for a total of $680 \mathrm{yr}$ (1329-2008). The long simulation was required to allow the slow carbon pools to come to equilibrium. There was an initial spin-up of $386 \mathrm{yr}$ (from 1329-1715) under constant preindustrial atmospheric $\mathrm{CO}_{2}$ values (278 ppm). The spin-up simulation started from near bare ground until soil carbon, vegetation structure and biomass achieved an equilibrium state. The runs were continued from 1715 up to 2008 with increasing prescribed atmospheric $\mathrm{CO}_{2}$ concentrations (from 278 to $386 \mathrm{ppm}$ ). During the entire $680 \mathrm{yr}$ run the prescribed climate was applied cyclically.

Soil texture data was based on the IGBP-DIS global soil and Quesada et al. (2010) data set. The control simulation (CA) and regional simulation (RS) used the regional map of texture, while the site level simulations used site level soil texture information from Quesada et al. (2010). The soil depth is considered homogeneous with $10 \mathrm{~m}$ in all simulations. There are 6 soil layers with thicknesses from the top layer to the bottom of $0.25,0.375,0.625,1.25,2.5,5 \mathrm{~m}$ depth.

No land use changes or other disturbances (e.g. fire) were incorporated in the simulations. Therefore, the results are for potential vegetation conditions (the vegetation in equilibrium with the prescribed soil and climate). Potential vegetation simulations were chosen because they should be most comparable to the field data, which were collected in undisturbed old-growth tropical forest plots

\subsection{Statistical Analyses}

The simulated variables are averaged for the last $10 \mathrm{yr}$ of simulation (1999-2008) and compared to the field data within a grid cell, which represent an average of the period of sampling. For statistical comparison we use the correlation coefficient, linear regression and the index of agreement (Willmott, 1982). The index of agreement provides information on how correlated and how distant the simulated data points are from the reference (observation), while the correlation coefficient might have a high value just because the data are well correlated even if not necessarily close in absolute values.
The index of agreement varies from 0 to 1 where 0 means a very poor agreement and 1 the maximum agreement.

\section{Results}

\subsection{Comparison of simulations and field observations}

We performed a series of sensitivity analyses with the model to identify the factors affecting the spatial variability of IBISsimulated woody productivity and biomass (Supplement A and B). The sensitivity analyses indicated that spatially varying values of maximum RuBisCO were important for accurate simulation of $\mathrm{NPP}_{\mathrm{w}}$ (Supplement Table B). Woody residence time was identified as the most relevant factor for reproducing the spatial variability in above-ground biomass (Supplement Table B). In this section we quantify how the site-specific observed parameter information (SS, Table 2) affected simulated productivity and biomass compared to the homogeneous parameter assumption (CA and SA3a, Table 2). These heterogeneous parameterization simulation results (SS) were compared to observations available for wood productivity and above-ground biomass (Fig. 7).

\subsubsection{Homogeneous parameterization}

The simulated $\mathrm{NPP}_{\mathrm{w}}$ in the control simulation (CA, where carbon allocation to wood is defined as $50 \%$,) is systematically overestimated compared to the observations (Fig. 7a, dark square). The simulated $\mathrm{NPP}_{\mathrm{w}}$ in (SA3a, where carbon allocation to wood is defined as $34 \%$ ) is in better agreement with the average observed values (Fig. 7a, dark triangles). The spatial variation of the observed $\mathrm{NPP}_{\mathrm{w}}$ was not reproduced in these simulations.

Similar analyses were performed for the above-ground biomass comparison (Fig. 7b). The simulated biomass in the control (CA) does not reproduce the spatial variation, but average values are similar to the observed (Fig. $7 b$, dark square). If only one of the parameters is corrected, for example carbon allocation (SA3a, dark triangle), the estimated biomass deviates strongly from the observations (Fig. 7b), which is consistent with results with the DVM ORCHIDEE (Delbart et al., 2009).

\subsubsection{Heterogeneous parameterization}

The results from simulations that include the combined effects of all site level heterogeneous parameterizations are presented in this section (Fig. 7, red and black).

The $\mathrm{NPP}_{\mathrm{w}}$ analyses are made for two series of data. The first considers only the data points where field estimates of $V_{\mathrm{cmax}}$ are available (Fig. 7a and c, in red), hereinafter Series $\mathrm{A}$. The second data series includes data points where the $V_{\mathrm{cmax}}$ has been extrapolated to all other locations where there are $\mathrm{NPP}_{\mathrm{w}}$ measurements (Table 1), hereinafter Series B (Fig. 7c, in black). The full set of $\mathrm{NPP}_{\mathrm{w}}$ that include sites 

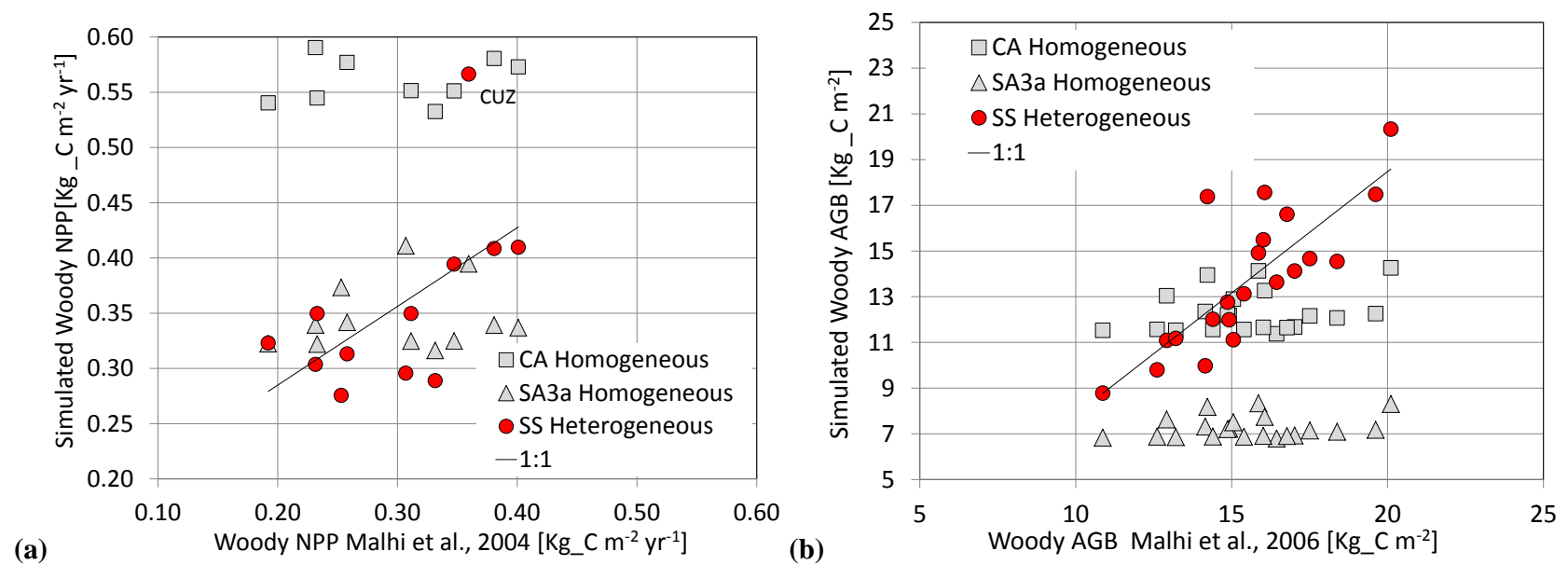

(a)

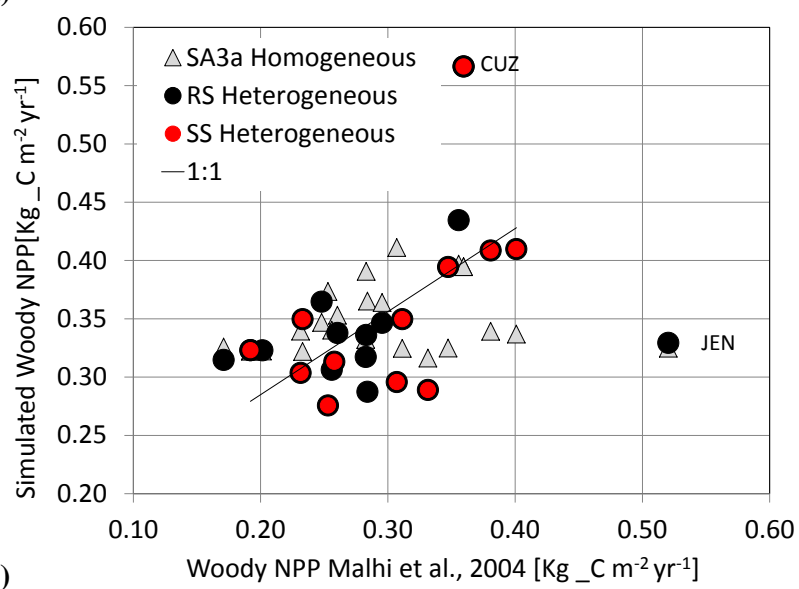

(b)

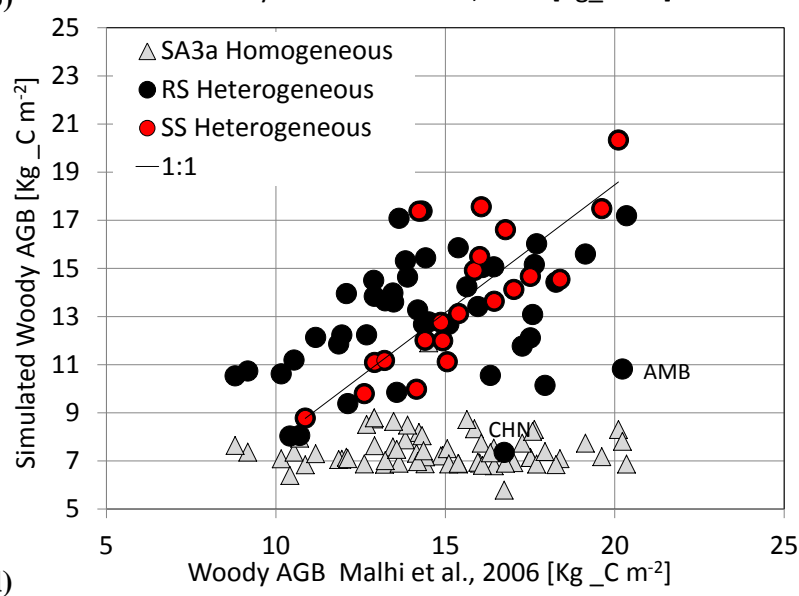

Fig. 7. Comparison of IBIS-simulated values with field observations. Figures on the left (a, c) are comparisons of woody above-ground net primary productivity. Figures on the right $(\mathbf{b}, \mathbf{d})$ are comparisons of woody above-ground live biomass. (a) and (b) are IBIS-simulated results, only for grid cells where the $V_{\mathrm{cmax}}$ (Series A) and woody residence time (Series B) are known; while (c) and (d) are the IBIS-simulated results for the full series of data where $\mathrm{NPP}_{\mathrm{w}}$ and $\mathrm{AGB}_{\mathrm{w}}$ field data are available (Series $\mathrm{A}+\mathrm{B}$ and $\mathrm{C}+\mathrm{D}$ ).

with known $V_{\text {cmax }}$ from field and extrapolated $V_{\text {cmax }}$ in this work is called Series A + B (Fig. 7c, in red and black).

The $\mathrm{NPP}_{\mathrm{w}}$ from simulation SS with heterogeneous parameterization (Fig. 7a, red circles) shows better agreement with the observations when compared to the previous homogeneous assumption SA3a (Fig. 7a, triangles). The coefficient of correlation improves from 0.10 to 0.71 , the regression slope (error) improves from $-0.04(0.03)$ to $0.6(0.2)$, and intercept (error) from $0.35(0.05)$ to $0.16(0.07)$ (Table 3 , Series $\mathrm{A}$ ). The slope coefficient improves but is still low, indicating that $\mathrm{NPP}_{\mathrm{w}}$ is overestimated by the model where observed values are low (Fig. 7a). The $\mathrm{NPP}_{\mathrm{w}}$ simulated by IBIS with the new spatial parameterization agrees better with the observed spatial variability. The index of agreement (Fig. 7a, Table 3) increases from 0 (SA3a, Series A) to 0.7 (SS, Series A).

The comparison of results of Series B (extrapolated parameterization) in simulation RS with SA3a (Table 3, Fig. 7c in black only) shows that some locations are closer to the observations (index of agreement 0.4 compared to 0.3 ) but the correlation is not improved (coefficient of correlation 0.66 compared to 0.79). This indicates, as expected, that the regionalized parameter data are not as good as site-specific field estimates. However, the conclusions for the regionalization of $\mathrm{NPP}_{\mathrm{w}}$ are still limited to a validation against only 10 data points that are not representative of the entire basin.

Similar to $\mathrm{NPP}_{\mathrm{w}}, \mathrm{AGB}_{\mathrm{w}}$ comparisons were made for two series: one including only the data points where woody residence time estimates are known (Fig. 7b, in red), referred to as Series C. The second data series includes locations where the woody residence time is extrapolated to all other $\mathrm{AGB}_{\mathrm{w}}$ data collection points, called Series D (Fig. 7d, in black). The full set of simulated $\mathrm{AGB}_{\mathrm{w}}$ values derived from both direct measurements of residence time and the extrapolations is called Series $\mathrm{C}+\mathrm{D}$ (Fig. 7d, in red and black). The heterogeneous woody residence time data has the strongest influence on the simulated spatial variability of $\mathrm{AGB}_{\mathrm{w}}$ (Fig. 7b, red circles). The data series SS captures the spatial variability of the $\mathrm{AGB}_{\mathrm{w}}$ much better than the SA3a simulation with homogeneous parameterizations (dark triangles). The 
Table 2. Summary of the parameterization setup for each of the simulation experiments: the control simulation (CA) with the original IBISprescribed homogeneous parameterization; the SA3a with corrected carbon allocation, with homogeneous parameterizations in space; site level simulation (SS) with heterogeneous parameterizations represented; and the regional simulation (RS) with the upscale of the respective parameters.

\begin{tabular}{|c|c|c|c|c|c|}
\hline & & \multicolumn{2}{|c|}{$\begin{array}{c}\text { Homogeneous } \\
\text { Parameterization }\end{array}$} & \multicolumn{2}{|c|}{$\begin{array}{c}\text { Heterogeneous } \\
\text { Parameterizations }\end{array}$} \\
\hline & & $\begin{array}{l}\text { (CA) } \\
\text { Control simulation } \\
\text { IBIS original setup }\end{array}$ & $\begin{array}{l}(\mathrm{SA} 3 \mathrm{a}) \\
\mathrm{CA} \text { with change } \\
\text { in } \mathrm{C} \text { allocation }\end{array}$ & $\begin{array}{l}\text { (SS) } \\
\text { Site level simu- } \\
\text { lation Site-based } \\
\text { observation data }\end{array}$ & $\begin{array}{l}\text { (RS) } \\
\text { Regional simulation } \\
\text { Regional estimated } \\
\text { data }\end{array}$ \\
\hline $\begin{array}{l}\text { Woody biomass residence } \\
\text { time }\end{array}$ & years & Constant in space 25 & Constant in space 25 & Dots in Fig. $5 b$ & Map in Fig. $5 b$ \\
\hline
\end{tabular}

Table 3. Statistical summary of the comparison of woody net primary productivity between IBIS-simulated results and field estimates. The table presents the number of data points within the studied area, mean and standard deviation, regression slope, intercept and correlation coefficient, and index of agreement (d). The statistical analyses were made for all sites excluding four outliers (JEN, CAQ, SCR, CUZ, discussed in Supplement D). The statistical analyses were divided in groups of data point as follows: Series A and B represent the series of all data points that have available $\mathrm{NPP}_{\mathrm{w}}$ field information; Series A represents the series of data where the $V_{\mathrm{cmax}}$ was estimated based on field information; and Series B represents all other data points where $\mathrm{NPP}_{\mathrm{w}}$ field was known and $V_{\mathrm{cmax}}$ was extrapolated based on the methodology described in this work.

\begin{tabular}{lrrrrrr}
\hline $\begin{array}{l}\text { Woody NPP } \\
{\left[\mathrm{kg}-\mathrm{C} \mathrm{m}^{-2} \mathrm{yr}^{-2}\right]}\end{array}$ & $\begin{array}{r}\text { \# data } \\
\text { points }\end{array}$ & $\begin{array}{r}\text { Mean } \\
(\text { Stdev })\end{array}$ & $\begin{array}{r}\text { a slope } \\
(\text { Stdev })\end{array}$ & $\begin{array}{r}\text { b intercept } \\
\text { (Stdev) }\end{array}$ & $\begin{array}{r}\text { Correlation } \\
\text { coefficient R }\end{array}$ & $\begin{array}{r}\text { d index of } \\
\text { agreement } \\
\text { Willmott } \\
\text { et al. (1982) }\end{array}$ \\
\hline Observed Series A & 10 & $0.31(0.06)$ & & & \\
Observed Series B & 9 & $0.27(0.04)$ & & & -0.1 & 0 \\
SA3a Series A & 10 & $0.34(0.03)$ & $-0.04(0.15)$ & $0.35(0.05)$ & 0.79 & 0.3 \\
SA3a Series B & 10 & $0.36(0.03)$ & $0.49(0.14)$ & $0.22(0.04)$ & 0.71 & 0.7 \\
SS Series A & 9 & $0.34(0.05)$ & $0.58(0.20)$ & $0.16(0.07)$ & 0.66 & 0.4 \\
RS Series B & 9 & $0.34(0.04)$ & $0.62(0.30)$ & $0.17(0.08)$ & & \\
\hline
\end{tabular}

coefficient of correlation of simulated woody above-ground biomass improves from 0.22 with homogeneous parameterization (SA3a, Series C) to 0.80 with spatial varying parameters (SS, Series C). The regression analyses show a significant improvement of the slope(error) from $0.05(0.05)$ to 1.06(0.18), and intercept(error) from 6.5(0.8) to $-2.8(2.8)$ (Table 4, Series C). The index of agreement in Series C improved from 0 with homogeneous parameterization (Table 4, Series C, SA3a) to 0.8 with heterogeneous parameterization
(Table 4, Series C, SS). Some outliers were identifyed and are discussed in detail in Supplement D.

The statistical analyses of $\mathrm{AGB}_{\mathrm{w}}$ from Series D (with the extrapolated woody residence time) provide a measure of the value of the extrapolation adopted in this work (Table 4, Series D). The results show improvement of all statistical parameters comparing the regional simulation (RS, Series D) to the homogeneous assumption (SA3a, Series D). The coefficient of correlation improved from -0.006 to 0.52 and the index of agreement from 0 to 0.6. As expected, the results 
Table 4. Statistical summary of the comparison of wood above-ground biomass between IBIS-simulated results and field estimates. The table presents the number of data points within the studied area, mean and standard deviation, regression slope, intercept and correlation coefficient, and index of agreement (d). The statistical analyses were made for all sites excluding three (CUZ, CHN and AMB, in Supplement D). The statistical analyses were divided in groups of data point as follows: Series C and D represent the series of all data points that have available $\mathrm{AGB}_{\mathrm{W}}$ field information; Series $\mathrm{C}$ represents the series of data where the woody residence time was estimated based on field information; and Series D represents all other data points where $\mathrm{AGB}_{\mathrm{w}}$ field was known and woody residence time was extrapolated based on the methodology described in this work.

\begin{tabular}{|c|c|c|c|c|c|c|}
\hline $\begin{array}{l}\text { Woody AGB } \\
{\left[\mathrm{kg}-\mathrm{C} \mathrm{m}^{-2}\right]}\end{array}$ & $\begin{array}{l}\text { \# data } \\
\text { points }\end{array}$ & $\begin{array}{r}\text { Mean } \\
(\text { Stdev) }\end{array}$ & a slope & $\mathrm{b}$ intercept & $\begin{array}{l}\text { Correlation } \\
\text { coefficient } R\end{array}$ & $\begin{array}{l}\mathrm{d} \text { indice of } \\
\text { agreement }\end{array}$ \\
\hline Obs & 21 & 15.4 & & & & \\
\hline Obser & 42 & 14.3( & & & & \\
\hline SA3a Series C & 21 & $7.3(0.5)$ & $0.05(0.05)$ & $6.5(0.8)$ & 0.22 & 0 \\
\hline SA3a Series D & 42 & $7.6(0.6)$ & $0.002(0.050)$ & 8) & -0.006 & 0 \\
\hline SS Series C & 21 & $13.7(2.3)$ & $1.06(0$ & -2.8 & 0.80 & 0.8 \\
\hline RS Series D & 42 & $13.1(2.6)$ & $0.44(0.71)$ & $6.9(1.1)$ & 0.52 & 0.6 \\
\hline
\end{tabular}

derived from extrapolated parameters (RS, Series D) are in poorer agreement with the results derived from SS Series C where residence time is site measured, with a lower slope (0.44) and intercept of 6.9 and larger variance of the distribution differences (6.5 compared to 3.3 in Series C).

\subsection{Regional Simulation Analyses (RS)}

In this section we present the basin-wide simulated woody above-ground productivity and biomass (simulation RS), based on our maps of spatially varying parameters (Table 1, Fig. 5). Quantitative validation of simulated $\mathrm{NPP}_{\mathrm{w}}$ and $\mathrm{AGB}_{\mathrm{w}}$ was discussed in Sect. 3.1 (Table 3, Series B; Table 4, Series D) at the specific locations in the basin. Qualitatively, there is much greater spatial variation of the $\mathrm{NPP}_{\mathrm{w}}$ and $\mathrm{AGB}_{\mathrm{w}}$ across the basin in the RS simulation (Fig. $8 \mathrm{c}$ and d) compared to CA (Fig. 8a and b).

The simulated $\mathrm{NPP}_{\mathrm{w}}$ spatial variability (Fig. 8c) follows the soil total phosphorus map patterns (Fig. 4). There is higher productivity in the west where the fertility is higher and also in central west Amazonia where P content is higher and the soil is silt. The productivity decreases in central and east Amazonia and increases again in the northeast. There is a region of low $\mathrm{NPP}_{\mathrm{w}}$ in northern Brazil and southern Venezuela due to the low estimated soil fertility in that area. A qualitative comparison of this simulation with a published satellite-derived map of NPP in Amazonia (Nunes et al., 2012) suggests similarities in spatial variability. A detailed analysis of the comparison of these simulations including land use change and other disturbances and comparison with satellite products is in progress and will be addressed in a different study.

The biomass map shows a west-to-east trend of higher biomass in central and northeastern Amazonia (RS, Fig. 8d) that is qualitatively consistent with the observed field data. The simulated spatial variability is linked to the woody residence time map. The biomass map (Fig. 8d) can be qualita- tively compared to the estimated biomass map from Malhi et al. (2006). Both maps suggest higher biomass occurs in the central and northeastern Amazon and lower biomass in the west and south. In the central Amazon the highest biomass values in the Malhi et al. (2006) data set are clustered around the sites of measurement, which is most likely an effect of extrapolation from the few data points available (Malhi et al., 2006). The gradient of biomass in the transition to the savanna environment in the southeast diverges in the absolute values from the Malhi et al. (2006) estimates. There is little field data for this region, making validation difficult.

\section{Discussion}

From this modeling exercise we have identified six major points regarding the controls on and importance of spatial variation in above-ground productivity and biomass.

\subsection{Homogeneous parameterizations and climate alone do not capture the spatial variability of woody above-ground productivity $\left(\mathbf{N P P}_{\mathrm{w}}\right)$ and biomass $\left(A_{G B}\right)$ present in the field data}

The results suggest that models may be able to simulate average $\mathrm{NPP}_{\mathrm{w}}$ and $\mathrm{AGB}_{\mathrm{w}}$ in reasonable agreement with observations but sometimes because of compensation of errors. For example, in simulation CA (the woody carbon allocation parameter is $50 \%$ and the woody residence time is $25 \mathrm{yr}$ ) the resulting average biomass is in relatively good agreement with observations (Fig. 7b, dark square). As discussed earlier, those parameter values, although commonly used, have been shown by observations to be incorrect. Using a high woody allocation rate (50\% vs $34 \%$ observed) and low residence time ( $25 \mathrm{yr}$ vs. $25-100 \mathrm{yr}$ observed) causes a large carbon allocation each year but low turnover rate and coincidently total biomass in good agreement with observations. In addition, the simulated results using homogeneous parameters do 

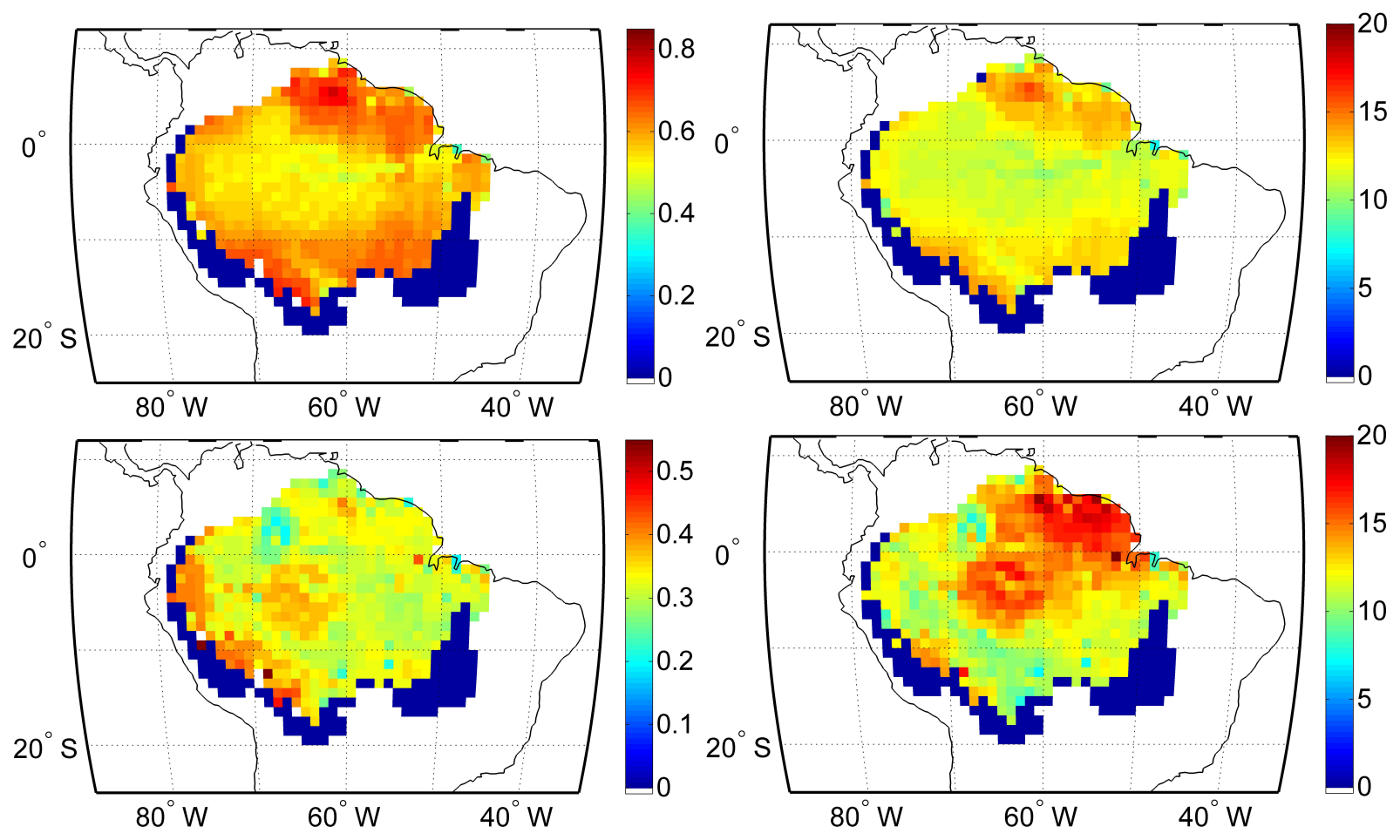

Fig. 8. Woody above-ground net primary productivity (left column, $\mathrm{NPP}_{\mathrm{w}}\left[\mathrm{kg}-\mathrm{C} \mathrm{m}^{-2} \mathrm{yr}^{-1}\right]$ ) and the woody above-ground live biomass (right column, $\mathrm{AGB}_{\mathrm{W}}\left[\mathrm{kg}-\mathrm{C} \mathrm{m}^{-2}\right]$ ). The first row presents the regional simulation under the control scenario (CA). The second row presents the IBIS-simulated map based on the upscaled parameterization (RS).

not capture the observed spatial variability of $\mathrm{NPP}_{\mathrm{w}}(260 \%$, the highest value is 3.6 times higher than the lowest value; Malhi et al., 2004) and $\mathrm{AGB}_{\mathrm{w}}(120 \%$, highest value is 2.2 times higher than the lowest value; Malhi et al., 2006) across the Amazon basin (Fig. 7a and b dark square).

There is relatively large spatial variation in the Amazon climate. However, field data analyses have shown poor correlation between climate variables and large-scale variation of productivity and biomass patterns in the basin (Malhi et al., 2004; Quesada et al., 2012; Galbraith et al., 2013). An analysis of the spatial patterns of productivity (Malhi et al., 2004) found no obvious relationship between the spatial distribution of wood productivity and precipitation, dry season length, or radiation, but the authors did find some decline in woody productivity with increasing temperature. However, the lower temperature in western Amazonia is indirectly correlated to higher soil fertility in that region, making it difficult to directly correlate temperature and productivity given the strong correlation between productivity and soil fertility. In analyses of basal area spatial patterns, Malhi et al. (2006) found some correlation with dry season length and precipitation. The decline in basal area, however, was evident only with extreme water stress and long dry season length (more than 4 months).

The spatial variation of climate in the Amazon basin imparts simulated productivity and biomass variation of $35 \%$ and $45 \%$ from the basin average minimum (Table B). IBIS and most numerical models underestimate or do not explicitly consider mortality rates due to short- or long-term disturbances such as temperature extremes, drought or flooding (Phillips et al., 2010; Galbraith et al., 2013). However, because the observed data were collected at sites specifically chosen to be free of recent disturbance, lack of climate-stress mortality is not a factor in the simulated low sensitivity to climate variation. Therefore, the low variability as a function of climate in the IBIS simulations appears to be a robust indication of the scale of the actual variability imparted by climate.

\subsection{Maximum carboxylation capacity of RuBisCO activity $\left(V_{\text {cmax }}\right)$ as a function of soil fertility is the primary variable controlling the simulated variation of woody above-ground productivity across the Amazon}

Observations suggest that soil fertility plays an important role in creating spatial variation of productivity across the Amazon basin, but little is known about the specific pathways (Quesada et al., 2012; Aragão et al., 2009, Malhi et al., 2004). Some of the possible factors that have been explored are differences in gross primary productivity, respiration rates, and carbon allocation between carbon pools. 
Malhi et al. (2004) suggest that carbon allocation may be related to the spatial variability of $\mathrm{NPP}_{\mathrm{w}}$, due to shifts in allocation to roots in less fertile soils. Alternatively the author's data analyses also suggest that carbon use efficiency $(\mathrm{CUE}=\mathrm{NPP} / \mathrm{GPP})$ is higher in the west, which suggests that in addition to a potentially higher GPP in the higher fertility soils of the western Amazon, there are also potentially higher autotrophic respiration rates in the lower fertility soils of central Amazonia. We found that alteration of GPP and autotrophic respiration achieved through a change in leaf photosynthetic capacity (related to maximum carboxylase capacity of RuBisCO) is the strongest candidate to explain the spatial variability of productivity. The sensitivity tests show that spatial variation of RuBisCO (from 75$40 \mu \mathrm{mol} \mathrm{CO} \mathrm{Cm}^{-2} \mathrm{~s}^{-1}, \mathrm{SA} 5$, Table A) leads to a simulated 60-80\% change in $\mathrm{NPP}_{\mathrm{w}}$ (Table B). A shift in woody carbon allocation from $50 \%$ to $25 \%$ imparts a $60 \%$ change in $\mathrm{NPP}_{\mathrm{w}}$ (Table B). Our analyses suggest that $V_{\text {cmax }}$ driven by soil fertility plays a stronger role than carbon allocation in the spatial variability of $\mathrm{NPP}_{\mathrm{w}}$.

\subsection{Heterogeneous parameterizations of key biophysical properties based on site-specific data improves the simulated woody above-ground productivity compared to homogeneous parameterizations}

We estimated the maximum carboxylation capacity of Ru$\mathrm{BisCO}$ as a function of site-observed total soil P from Quesada et al. (2010). This estimate was based on the established correlation between $V_{\text {cmax }}$ and leaf $\mathrm{P}$ content (Mercado et al., 2009, 2011), and the understanding that leaf nutrients are directly related to soil nutrients (Fyllas et al., 2009), The spatial heterogeneity of other parameters of minor effect in the $\mathrm{NPP}_{\mathrm{w}}$ calculation, such as carbon allocation, woody residence time, and specific leaf area, were also derived based on published site field data. The IBIS-simulated $\mathrm{NPP}_{\mathrm{w}}$ using heterogeneous parameterization was compared to $\mathrm{NPP}_{\mathrm{w}}$ field data (Malhi et al., 2004).

As presented in the Results (Sect. 3) the use of heterogeneous parameterizations in IBIS based on field data significantly improved the simulation of $\mathrm{NPP}_{\mathrm{w}}$ (correlation coefficient -0.1 to 0.71 , respectively, for the homogeneous and heterogeneous parameterization, Table 3). The simulated $\mathrm{NPP}_{\mathrm{w}}$ values at the lower end of the observations were not well captured by the model as indicated by a slope of $0.58 \pm 0.20$ and an offset of $0.16 \pm 0.07$ (Table 3 ). This could be due to an overestimation of the $V_{\text {cmax }}$ for low-fertility sites or by other factors that are not captured by the model. For example, lowland areas may have higher respiration rates than what the model predicts, due to the higher temperatures and/or the higher respiratory costs due to slower plant growth in less fertile soils (Malhi et al., 2004). These effects may not be fully represented in IBIS and may contribute to the overestimation of the low end of $\mathrm{NPP}_{\mathrm{w}}$, in central and east Amazo- nian sites. A detailed analysis of field information on the respiration rates, available biomass in decomposition state and how the model reproduces these processes needs to be addressed in the future. A factor that may be contributing to a general overestimation of $\mathrm{NPP}_{\mathrm{w}}$ is the simulated Leaf Area Index (LAI). The LAI in the model is systematically higher than the observations, which would cause an increase in simulated NPP. Each year, because of increasing atmospheric $\mathrm{CO}_{2}$ there is more carbon to allocate, and the allocation in the model is constant in time as is the residence time of the leaves. Therefore, the LAI in the model increases with time. The assumption of constant allocation and residence time is probably too simplistic, but the right balance of changes in carbon allocation between the plant components in space and time is poorly known.

In our analyses we observed that the differences of simulated $\mathrm{NPP}_{\mathrm{w}}$ from the observations do not appear to be related to misrepresentation of carbon allocation. For example, if we define woody carbon allocation to a value that minimizes the $\mathrm{NPP}_{\mathrm{w}}$ error, then the carbon allocation to wood would have to be unrealistically low $(0.15-0.25$ compared to the observed values $0.25-0.5$ ). There are most likely other unknown factors contributing to the lack of good agreement, including shorter timescale variability of parameter response to drought, fertility and disturbance for which we do not yet have data. Further improvements of these parameters are clearly required and are discussed in suggestion for future work below.

\subsection{Woody residence time is the most important mechanism affecting the magnitude and spatial distribution of simulated $\mathrm{AGB}_{\mathrm{w}}$}

Our results of the IBIS sensitivity analyses suggest that woody residence time is the most important mechanism affecting the magnitude and spatial distribution of simulated $\mathrm{AGB}_{\mathrm{w}}$. This result is in agreement with the analyses of Senna et al. (2009) and Delbart et al. (2010). Spatial variation of woody residence time within the range of 25 to $100 \mathrm{yr}$ changes simulated $\mathrm{AGB}_{\mathrm{w}}$ by $180 \%$ from the basin minimum (Table B).

\subsection{Heterogeneous parameterizations of key biophysical properties based on site-specific data improves the simulated woody above-ground biomass when compared to homogeneous parameterizations}

We used field data available for 21 sites across the Amazon basin to represent the spatial heterogeneity of woody residence time (Phillips et al., 2004; Galbraith et al., 2013). The spatial variability of other parameters of minor effect in $\mathrm{AGB}_{\mathrm{w}}$ such as carbon allocation, $V_{\mathrm{cmax}}$, and specific leaf area index were also included in the simulation of AGB. 
The comparison of the simulated $\mathrm{AGB}_{\mathrm{w}}$ with observations showed an improvement in the coefficient of correlation from 0.22 in the homogeneous experiments (SA3a) to 0.80 in the heterogeneous ones (SS) (Table 4). The regression fit is much closer to the 1:1 relation. The good agreement comes from two factors: one is that the AGB simulated by the model was based on residence times estimated from field data; the other is that most of the sites for comparisons of biomass come from direct measurement of individual trees (Baker et al., 2004b). As a result, both model and field measurement methodologies used the most accurate information available.

\subsection{The regional maps of key parameter values developed in this study significantly improve simulated $\mathrm{AGB}_{\mathrm{w}}$ compared to simulations using homogeneous parameterization assumptions}

The quality of the regional maps of the physiological properties depends on three factors: (1) the number of site level data points available; (2) how representative these sites are of the larger scale; and (3) how well we understand what drives the spatial variability of these properties. We developed a set of extrapolations of the observed field data to the entire Amazon basin in order to introduce greater heterogeneity into the simulations of $\mathrm{NPP}_{\mathrm{w}}$ and $\mathrm{AGB}_{\mathrm{w}}$. Unfortunately there are relatively few field data sites (Table 1) and the processes that govern the spatial variability are not completely understood, which makes our regional maps somewhat speculative.

The $V_{\text {cmax }}$ was extrapolated to the entire basin using a soil map of $\mathrm{P}$ and the regression equation between field-based $V_{\text {cmax }}$ and $\mathrm{P}$ (Table 1, Fig. 5c). The comparison of simulated $\mathrm{NPP}_{\mathrm{w}}$ (from the extrapolated $V_{\mathrm{cmax}}$ ) with observations was represented by a few points $(n=9)$. Although the simulated results for some of the individual data points were improved, it was not significant $(p>0.5)$ considering the small size of the sample.

We estimated woody biomass residence time for the entire basin based on a simple kriging interpolation (Fig. 5b). The large-scale spatial variability showed a trend of lower $\tau_{\mathrm{w}}$ in west than in central and east Amazonia, which is in qualitative agreement with the observations. The comparison of the basin-wide simulations suggests that this first attempt at spatially varying biophysical parameters improved the simulations. For example, the coefficient of correlation of simulated $\mathrm{AGB}_{\mathrm{w}}$ with observations at 46 locations increased $(0.52, \mathrm{RS})$ compared to the more standard homogeneous parameters $(\sim 0, \mathrm{CA})$ (Table 4$)$. The results showed that the proposed map of woody residence time, despite its uncertainties, was a better option than a homogeneous assumption for the entire basin.

Given the importance of the woody residence time in simulating the $\mathrm{AGB}_{\mathrm{w}}$, it is fundamental to understand the factors that govern its spatial distribution. However there is no single mechanism that is known to control its geographic pattern. Many authors have explored this topic including Quesada et al. (2012) who have argued that woody residence time is correlated with soil physical properties such as soil depth, soil structure and topography. However, residence time has also been found to be well correlated with soil fertility within the Amazon (Phillips et al., 2004; Galbraith et al., 2013). There are also other soil conditions, such as rooting depth limitations, low drainage capacity, poor soil structure, and topographic position that might affect woody residence time (Quesada et al., 2012). Delbart et al. (2010) presented an alternative solution of dynamic estimation of woody residence time as a function of NPP, whereby the function was defined based on the empirical correlation between them. This NPP-based assumption is, however, only valid for a forest in equilibrium, and the NPP needs to be well estimated by the model. This combination of poorly known governing factors makes it difficult to mechanistically determine residence time across the Amazon. We believe that our prescribed approach using a simplified interpolation is a good starting point, although we cannot assume residence times will remain unchanged under future scenarios of climate change.

\section{Conclusions}

This work has presented efforts at incremental improvement of numerical modeling of tropical broadleaf evergreen forests in the Amazon. It has identified some of the most important and relevant parameters for the simulation of $\mathrm{C}$ fluxes and stocks by a DGVM and shown the importance of spatial and temporal representation of functional diversity of tropical ecosystem modeling. This project has also helped identify several areas of research in data collection and model development that could lead to further improvements in model representation of tropical forest environments.

Accuracy of regional simulations is still limited by data scarcity of field data. Data needs include (1) expansion of the network of field data monitoring to a better characterization of the basin, (2) examination of the physiological processes that govern the spatial variability of the main parameterizations, and (3) development of new satellite and airborne measurements of key biophysical properties and mechanisms.

Accuracy is also limited by poor numerical representation of several important biophysical properties. Model improvements include (1) dynamic representation of disturbances such as land use change and fire, (2) improvement of model biophysical processes such as photosynthetic response to nutrient limitation and tree mortality as a function of drought stress, and (3) development of more-dynamic representations of PFTs to better characterize the functional diversity of tropical forests.

Continued stepwise improvement in models and data collection such as those described here will yield greater understanding of the spatial and temporal variations of forest carbon stocks throughout the tropics. 
Supplementary material related to this article is available online at: http://www.biogeosciences.net/10/ 2255/2013/bg-10-2255-2013-supplement.pdf.

Acknowledgements. We would like to thank the following people for their contributions: Santiago Cuadra, Hewlley Imbuzeiro and Alessandro da Fonseca for help in numerical model initialization; Eric Davidson for valuable discussions; Paul Lefebvre for creative graphical representations; and Justin Sheffield, Ryan Knox, Ke Zhang, Naomi Levine and Marcos Longo for preparation of soil texture and climatological data set. We also thank the referees for comments that significantly improved this manuscript. We gratefully thank Gordon and Betty Moore Foundation for funding this work.

Edited by: U. Seibt

\section{References}

Aragão, L. E. O. C., Malhi, Y., Metcalfe, D. B., Silva-Espejo, J. E., Jiménez, E., Navarrete, D., Almeida, S., Costa, A. C. L., Salinas, N., Phillips, O. L., Anderson, L. O., Alvarez, E., Baker, T. R., Goncalvez, P. H., Huamán-Ovalle, J., Mamani-Solórzano, M., Meir, P., Monteagudo, A., Patiño, S., Peñuela, M. C., Prieto, A., Quesada, C. A., Rozas-Dávila, A., Rudas, A., Silva Jr., J. A., and Vásquez, R.: Above- and below-ground net primary productivity across ten Amazonian forests on contrasting soils, Biogeosciences, 6, 2759-2778, doi:10.5194/bg-6-2759-2009, 2009.

Baker, T. R., Phillips, O. L., Malhi, Y., Almeida, S., Arroyo, L., Di Fiore, A., Erwin, T., Higuchi, N., Killeen, T. J., Laurance, S. G., Laurance, W. F., Lewis, S. L., Monteagudo, A., Neill, D. A., Núñez Vargas, P., Pitman, N. C. A., Silva, J. N. M., and Vásquez Martínez, R.: Increasing biomass in Amazonian forest plots, Philos. T. Roy. Soc. Lond. B, 359, 353-365, doi:10.1098/rstb.2003.1422, 2004a.

Baker, T. R., Phillips, O. L., Malhi, Y., Almeida, S., Arroyo, L., Di Fiore, A., Erwin, T., Killeen, T. J., Laurance, S. G., Laurance, W. F., Lewis, S. L., Lloyd, J., Monteagudo, A., Neill, D. A., Patiño, S., Pitman, N. C. A., M. Silva, J. N., and Vásquez Martínez, R.: Variation in wood density determines spatial patterns inAmazonian forest biomass, Glob. Change Biol., 10, 545562, doi:10.1111/j.1365-2486.2004.00751.x, 2004b.

Coe, M. T., Costa, M. H., and Howard, E. A.: Simulating the surface waters of the Amazon River basin: impacts of new river geomorphic and flow parameterizations, Hydrol. Process., 22, 14, 2542-2553, doi:10.1002/hyp.6850, 2007.

Davidson, E. A., De Araujo, A. C., Artaxo, P., Balch, J. K., Brown, I. F., C. Bustamante, M. M., Coe, M. T., Defries, R. S., Keller, M., Longo, M., Munger, J. W., Schroeder, W., Soares-Filho, B. S., Souza, C. M., and Wofsy, S. C.: The Amazon basin in transition, Nature, 481, 321-328, 2012.

Delbart, N., Ciais, P., Chave, J., Viovy, N., Malhi, Y., and Le Toan, T.: Mortality as a key driver of the spatial distribution of aboveground biomass in Amazonian forest: results from a dynamic vegetation model, Biogeosciences, 7, 3027-3039, doi:10.5194/bg-7-3027-2010, 2010.
Delire, C. and Foley, J. A.: Evaluating the performance of a land surface/ecosystem model With biophysical measurements from contrasting environments, J. Geophys. Res.-Atmos., 104, 1689516909, 1999.

Domingues, T. F., Berry, J. A., Martinelli, L. A., Ometto, J. P. H. B., and Ehleringer, J. R.: Parameterization of Canopy Structure and Leaf-Level Gas Exchange for an Eastern Amazonian Tropical Rain Forest (Tapajós National Forest, Pará, Brazil), Earth Interact., 9, 1-23, doi:10.1175/ei149.1, 2005.

Domingues, T. F., Meir, P., Feldpausch, T. R., Saiz, G., Veenendaal, E. M., Schrodt, F., Bird, M., Djagbletey, G., Hien, F., Compaore, H., Diallo, A., Grace, J., and Lloyd, J. O. N.: Colimitation of photosynthetic capacity by nitrogen and phosphorus in West Africa woodlands, Plant Cell Environ., 33, 959-980, doi:10.1111/j.1365-3040.2010.02119.x, 2010.

Eva, H. D., Huber, O., Achard, F., Balslev, H., Beck, S., Behling, H., Belward, A. S., Beuchle, R., Cleef, A., Colchester, M., Muller, J. M., Pereira., J. M., Peres, C., Prance, G. T., Roberts, J. M., and Salo, J.: A proposal for defining the geographical boundaries of Amazonia, Report, Eurpean Communities, Luxembourg, 2005.

Feldpausch, T. R., Banin, L., Phillips, O. L., Baker, T. R., Lewis, S. L., Quesada, C. A., Affum-Baffoe, K., Arets, E. J. M. M., Berry, N. J., Bird, M., Brondizio, E. S., de Camargo, P., Chave, J., Djagbletey, G., Domingues, T. F., Drescher, M., Fearnside, P. M., França, M. B., Fyllas, N. M., Lopez-Gonzalez, G., Hladik, A., Higuchi, N., Hunter, M. O., Iida, Y., Salim, K. A., Kassim, A. R., Keller, M., Kemp, J., King, D. A., Lovett, J. C., Marimon, B. S., Marimon-Junior, B. H., Lenza, E., Marshall, A. R., Metcalfe, D. J., Mitchard, E. T. A., Moran, E. F., Nelson, B. W., Nilus, R., Nogueira, E. M., Palace, M., Patiño, S., Peh, K. S.H., Raventos, M. T., Reitsma, J. M., Saiz, G., Schrodt, F., Sonké, B., Taedoumg, H. E., Tan, S., White, L., Wöll, H., and Lloyd, J.: Height-diameter allometry of tropical forest trees, Biogeosciences, 8, 1081-1106, doi:10.5194/bg-8-1081-2011, 2011.

Foley, J. A., Prentice, I. C., Ramankutty, N., Levis, S., Pollard, D., Sitch, S., and Haxeltine, A.: An integrated biosphere model of land surface processes, terrestrial carbon balance, and vegetation dynamics, Global Biogeochem. Cy., 10, 603-628, 1996.

Foley, J. A., Botta, A., Coe, M. T., and Costa, M. H.: El Nino-Southern Oscillation and the Climate, Ecosystems and Rivers of Amazonia, Global Biogeochem. Cy., 16, 1132, doi:10.1029/2002GB001872, 2002.

Fyllas, N. M., Patiño, S., Baker, T. R., Bielefeld Nardoto, G., Martinelli, L. A., Quesada, C. A., Paiva, R., Schwarz, M., Horna, V., Mercado, L. M., Santos, A., Arroyo, L., Jiménez, E. M., Luizão, F. J., Neill, D. A., Silva, N., Prieto, A., Rudas, A., Silviera, M., Vieira, I. C. G., Lopez-Gonzalez, G., Malhi, Y., Phillips, O. L., and Lloyd, J.: Basin-wide variations in foliar properties of Amazonian forest: phylogeny, soils and climate, Biogeosciences, 6 , 2677-2708, doi:10.5194/bg-6-2677-2009, 2009.

Fyllas, N. M., Quesada, C. A., and Lloyd, J.: Deriving Plant Functional Types for Amazonian forests for use in vegetation dynamics models, Perspect. Plant Ecol., 14, 97-110, doi:10.1016/j.ppees.2011.11.001, 2012.

Galbraith, D., Malhi, Y., Affum-Baffoe, K., Castanho, A. D. A., Doughty, C. E., Fisher, R. A., Lewis, S, Peh, K. S. H., Phillips, O. L., Quesada, C. A., Sonké, B., and Lloyd, J.: Residence time of woody biomass in tropical forests, Plant Ecol. Divers., 1-19, doi:10.1080/17550874.2013.770578, 2013. 
Green, W. H. and Ampt, G. A.: Studies on soil physics, 1. The flow of air and water through soils, J. Agr. Sci., 4, 11-24, 1911.

Higgins, M. A., Ruokolainen, K., Tuomisto, H., Llerena, N., Cardenas, G., Phillips, O. L., Vásquez, R., and Räsänen, M.: Geological control of floristic composition in Amazonian forests, J. Biogeogr., 38, 2136-2149, doi:10.1111/j.1365-2699.2011.02585.x, 2011.

Kucharik, C. J., Foley, J. A., Delire, C., Fisher, V. A., Coe, M. T., Lenters, J. D., Young-Molling, C., Ramankutty, N., Norman, J. M., and Gower, S. T.: Testing the performance of a dynamic global ecosystem model: Water balance, carbon balance, and vegetation structure, Global Biogeochem. Cy., 14, 795-825, doi:10.1029/1999gb001138, 2000 .

Li, K. Y., Coe, M. T., and Ramankutty, N.: Investigation of Hydrological Variability in West Africa Using Land Surface Models, J. Climate, 18, 3173-3188, 2005.

Li, K. Y., De Jong, R., Coe, M. T., and Ramankutty, N.: RootWater-Uptake Based upon a New Water Stress Reduction and an Asymptotic Root Distribution Function, Earth Interact., 10, 1-22, doi:10.1175/EI177.1, 2006.

Lloyd, J., Patiño, S., Paiva, R. Q., Nardoto, G. B., Quesada, C. A., Santos, A. J. B., Baker, T. R., Brand, W. A., Hilke, I., Gielmann, H., Raessler, M., Luizão, F. J., Martinelli, L. A., and Mercado, L. M.: Optimisation of photosynthetic carbon gain and within-canopy gradients of associated foliar traits for Amazon forest trees, Biogeosciences, 7, 1833-1859, doi:10.5194/bg-71833-2010, 2010.

Malhi, Y.: The carbon balance of tropical forest regions, 1990-2005, Curr. Opin. Environ. Sustain., 2, 237-244, doi:10.1016/j.cosust.2010.08.002, 2010.

Malhi, Y.: The productivity, metabolism and carbon cycle of tropical forest vegetation, J. Ecol., 100, 65-75, doi:10.1111/j.13652745.2011.01916.x, 2012.

Malhi, Y., Phillips, O. L., Lloyd, J., Baker, T., Wright, J., Almeida, S., Arroyo, L., Frederiksen, T., Grace, J., Higuchi, N., Killeen, T., Laurance, W. F., Leaño, C., Lewis, S., Meir, P., Monteagudo, A., Neill, D., Núñez Vargas, P., Panfil, S. N., Patiño, S., Pitman, N., Quesada, C. A., Rudas-Ll, A., Salomão, R., Saleska, S., Silva, N., Silveira, M., Sombroek, W. G., Valencia, R., Vásquez Martínez, R., Vieira, I. C. G., and Vinceti, B.: An international network to monitor the structure, composition and dynamics of Amazonian forests (RAINFOR), J. Veg. Sci., 13, 439-450, doi:10.1111/j.1654-1103.2002.tb02068.x, 2002.

Malhi, Y., Baker, T. R., Phillips, O. L., Almeida, S., Alvarez, E., Arroyo, L., Chave, J., Czimczik, C. I., Fiore, A. D., Higuchi, N., Killeen, T. J., Laurance, S. G., Laurance, W. F., Lewis, S. L., Montoya, L. M. M., Monteagudo, A., Neill, D. A., Vargas, P. N., Patiño, S., Pitman, N. C. A., Quesada, C. A., Salomão, R., Silva, J. N. M., Lezama, A. T., Martínez, R. V., Terborgh, J., Vinceti, B., and Lloyd, J.: The above-ground coarse wood productivity of 104 Neotropical forest plots, Glob. Change Biol., 10, 563-591, doi:10.1111/j.1529-8817.2003.00778.x, 2004.

Malhi, Y., Wood, D., Baker, T. R., Wright, J., Phillips, O. L., Cochrane, T., Meir, P., Chave, J., Almeida, S., Arroyo, L., Higuchi, N., Killeen, T. J., Laurance, S. G., Laurance, W. F., Lewis, S. L., Monteagudo, A., Neill, D. A., Vargas, P. N., Pitman, N. C. A., Quesada, C. A., Salomão, R., Silva, J. N. M., Lezama, A. T., Terborgh, J., Martínez, R. V., and Vinceti, B.: The regional variation of aboveground live biomass in old-growth Amazonian forests, Glob. Change Biol., 12, 1107-1138, doi:10.1111/j.13652486.2006.01120.x, 2006.

Malhi, Y., Aragão, L. E. O. C., Metcalfe, D. B., Paiva, R., Quesada, C. A., Almeida, S., Anderson, L., Brando, P., Chambers, J. Q., Da Costa, A. C. L., Hutyra, L. R., Oliveira, P., Patiño, S., Pyle, E. H., Robertson, A. L., and Teixeira, L. M.: Comprehensive assessment of carbon productivity, allocation and storage in three Amazonian forests, Glob. Change Biol., 15, 1255-1274, doi:10.1111/j.1365-2486.2008.01780.x, 2009.

Malhi, Y., Doughty, C., and Galbraith, D.: The allocation of ecosystem net primary productivity in tropical forests, Philos. T. Roy. Soc. B, 366, 1582, 3225-3245, doi:10.1098/rstb.2011.0062, 2011.

Mercado, L. M., Lloyd, J., Dolman, A. J., Sitch, S., and Patiño, S.: Modelling basin-wide variations in Amazon forest productivity - Part 1: Model calibration, evaluation and upscaling functions for canopy photosynthesis, Biogeosciences, 6, 1247-1272, doi:10.5194/bg-6-1247-2009, 2009.

Mercado, L. M., Patiño, S., Domingues, T. F., Fyllas, N. M., Weedon, G. P., Sitch, S., Quesada, C. A., Phillips, O. L., Aragão, L. E. O. C., Malhi, Y., Dolman, A. J., Restrepo-Coupe, N., Saleska, S. R., Baker, T. R., Almeida, S., Higuchi, N., and Lloyd, J.: Variations in Amazon forest productivity correlated with foliar nutrients and modelled rates of photosynthetic carbon supply, Philos. T. Roy. Soc. B, 366, 3316-3329, doi:10.1098/rstb.2011.0045, 2011.

Nunes, E. L., Costa, M. H., Malhado, A. C. M., Dias, L. C. P., Vieira, S. A., Pinto, L. B., and Ladle, R. J.: Monitoring carbon assimilation in South America's tropical forests: Model specification and application to the Amazonian droughts of 2005 and 2010, Remote Sens. Environ., 117, 449-463, doi:10.1016/j.rse.2011.10.022, 2012.

Pan, Y., Birdsey, R. A., Fang, J., Houghton, R., Kauppi, P. E., Kurz, W. A., Phillips, O. L., Shvidenko, A., Lewis, S. L., Canadell, J. G., Ciais, P., Jackson, R. B., Pacala, S. W., Mcguire, A. D., Piao, S., Rautiainen, A., Sitch, S., and Hayes, D.: A Large and Persistent Carbon Sink in the World's Forests, Science, 333, 988 993, 10.1126/science.1201609, 2011.

Peacock, J., Baker, T. R., Lewis, S. L., Lopez-Gonzalez, G., and Phillips, O. L.: The RAINFOR database: monitoring forest biomass and dynamics, J. Veg. Sci., 18, 535-542, doi:10.1111/j.1654-1103.2007.tb02568.x, 2007.

Phillips, O. L., Baker, T. R., Arroyo, L., Higuchi, N., Killeen, T. J., Laurance, W. F., Lewis, S. L., Lloyd, J., Malhi, Y., Monteagudo, A., Neill, D. A., Núñez Vargas, P., Silva, J. N. M., Terborgh, J., Vásquez Martínez, R., Alexiades, M., Almeida, S., Brown, S., Chave, J., Comiskey, J. A., Czimczik, C. I., Di Fiore, A., Erwin, T., Kuebler, C., Laurance, S. G., Nascimento, H. E. M., Olivier, J., Palacios, W., Patiño, S., Pitman, N. C. A., Quesada, C. A., Saldias, M., Torres Lezama, A., and Vinceti, B.: Pattern and process in Amazon tree turnover, 1976-2001, Philos. T. Roy. Soc. Lond. B, 359, 381-407, doi:10.1098/rstb.2003.1438, 2004.

Phillips, O. L., Van Der Heijden, G., Lewis, S. L., López-González, G., Aragão, L. E. O. C., Lloyd, J., Malhi, Y., Monteagudo, A., Almeida, S., Dávila, E. A., Amaral, I., Andelman, S., Andrade, A., Arroyo, L., Aymard, G., Baker, T. R., Blanc, L., Bonal, D., De Oliveira, Á. C. A., Chao, K.-J., Cardozo, N. D., Da Costa, L., Feldpausch, T. R., Fisher, J. B., Fyllas, N. M., Freitas, M. A., Galbraith, D., Gloor, E., Higuchi, N., Honorio, E., Jiménez, 
E., Keeling, H., Killeen, T. J., Lovett, J. C., Meir, P., Mendoza, C., Morel, A., Vargas, P. N., Patiño, S., Peh, K. S. H., Cruz, A. P., Prieto, A., Quesada, C. A., Ramírez, F., Ramírez, H., Rudas, A., Salamão, R., Schwarz, M., Silva, J., Silveira, M., Ferry Slik, J. W., Sonké, B., Thomas, A. S., Stropp, J., Taplin, J. R. D., Vásquez, R., and Vilanova, E.: Drought-mortality relationships for tropical forests, New Phytol., 187, 631-646, doi:10.1111/j.1469-8137.2010.03359.x, 2010.

Quesada, C. A., Lloyd, J., Schwarz, M., Patiño, S., Baker, T. R., Czimczik, C., Fyllas, N. M., Martinelli, L., Nardoto, G. B., Schmerler, J., Santos, A. J. B., Hodnett, M. G., Herrera, R., Luizão, F. J., Arneth, A., Lloyd, G., Dezzeo, N., Hilke, I., Kuhlmann, I., Raessler, M., Brand, W. A., Geilmann, H., Moraes Filho, J. O., Carvalho, F. P., Araujo Filho, R. N., Chaves, J. E., Cruz Junior, O. F., Pimentel, T. P., and Paiva, R.: Variations in chemical and physical properties of Amazon forest soils in relation to their genesis, Biogeosciences, 7, 1515-1541, doi:10.5194/bg-7-15152010, 2010.

Quesada, C. A., Lloyd, J., Anderson, L. O., Fyllas, N. M., Schwarz, M., and Czimczik, C. I.: Soils of Amazonia with particular reference to the RAINFOR sites, Biogeosciences, 8, 1415-1440, doi:10.5194/bg-8-1415-2011, 2011.

Quesada, C. A., Phillips, O. L., Schwarz, M., Czimczik, C. I., Baker, T. R., Patiño, S., Fyllas, N. M., Hodnett, M. G., Herrera, R., Almeida, S., Alvarez Dávila, E., Arneth, A., Arroyo, L., Chao, K. J., Dezzeo, N., Erwin, T., di Fiore, A., Higuchi, N., Honorio Coronado, E., Jimenez, E. M., Killeen, T., Lezama, A. T., Lloyd, G., López-González, G., Luizão, F. J., Malhi, Y., Monteagudo, A., Neill, D. A., Núñez Vargas, P., Paiva, R., Peacock, J., Peñuela, M. C., Peña Cruz, A., Pitman, N., Priante Filho, N., Prieto, A.,
Ramírez, H., Rudas, A., Salomão, R., Santos, A. J. B., Schmerler, J., Silva, N., Silveira, M., Vásquez, R., Vieira, I., Terborgh, J., and Lloyd, J.: Basin-wide variations in Amazon forest structure and function are mediated by both soils and climate, Biogeosciences, 9, 2203-2246, doi:10.5194/bg-9-2203-2012, 2012.

Senna, M. C. A., Costa, M. H. C., Pinto, L. I. C., Imbuzeiro, H. M. A., Diniz, L. M. F., and Piriz, G. F.: Challenges to reproduce vegetation structure and dynamics in amazonia using a coupled climate-biosphere model, Earth Interact., 13, 1-28, doi:10.1175/2009EI281.1, 2009.

Sheffield, J., Goteti, G., and Wood, E. F.: Development of a 50Year High-Resolution Global Dataset of Meteorological Forcings for Land Surface Modeling, J. Climate, 19, 3088-3111, doi:10.1175/JCLI3790.1, 2006.

Thompson, S. L. and Pollard, D.: A Global Climate Model (GENESIS) with a Land-Surface Transfer Scheme (LSX), Part 2: $\mathrm{CO}_{2}$ Sensitivity, J. Climate, 8, 1104-1121, doi:10.1175/15200442(1995)008<1104:agcmwa>2.0.co;2, 1995a.

Thompson, S. L. and Pollard, D.: A Global Climate Model (GENESIS) with a Land-Surface Transfer Scheme (LSX), Part 2: Present Climate Simulation, J. Climate, 8, 732-761, doi:10.1175/1520-0442(1995)008<0732:agcmwa $>2.0$. co;2, 1995 b.

Vitousek, P. M.: Litterfall, Nutrient Cycling, and Nutrient Limitation in Tropical Forests, Ecology, 65, 285-298, 1984.

Willmott, C. J.: Some comments on the evaluation of model performance, B. Am. Meteorol. Soc., 63, 1309-1313, 1982. 